If you no longer need this publication write to the Geological Survey in Washington for an ofreial mailing label to ase in returning it

UNITED STATES DEPARTMENT OF THE INTERIOR

-

\title{
GROUND WATER IN THE \\ HigH PLAINS OF TEXAS
}

Prepared in cooperation with the TEXAS BOARD OF WATRR BNGINEIRS

GEOLOGICAL SURVEY WATER-SUPPLY PAPER 889-F

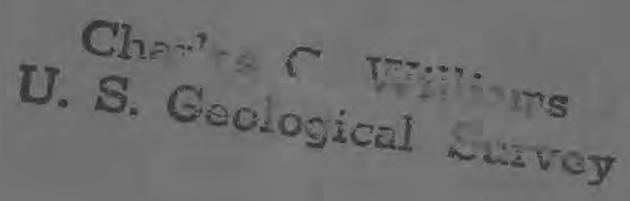




\section{UNITED STATES DEPARTMENT OF THE INTERIOR}

Harold L. Ickes, Secretary

GEOLOGICAL SURVEY

W. E. Wrather, Director

Water-Supply Paper 889-F

\section{GROUND WATER IN THE}

\section{HIGH PLAINS OF TEXAS}

BY

W. N. WHITE, W. L. BROADHURST

J. W. LANG

Prepared in cooperation with the

TEXAS BOARD OF WATER ENGINEERS

Contributions to the Hydrology of the United States, 1941-13

(Pages 381-421)

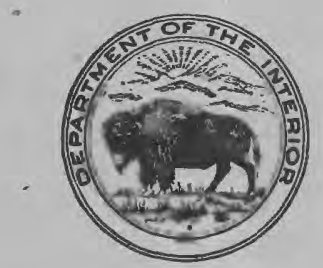

UNITED STATES

GOVERNMENT PRINTING OFFICE

WASHINGTON: 1946 



\section{CONTENTS}

Abstract

Introduction

Location and extent of area

Acknowledgments

Previous ground-water investigations

Source of the ground water.

Recharge from depression pond

Recharge from streams.

(atural disc in sand-hill areas......--

Discharge of ground water from escarpment springs and seeps

Discharge of ground water in shallow water-table areas on the High Plains.

Total natural discharge from the area

History of the development of ground water for irrigation

Use of ground water for irrigation, 1937-39

Plainview district

Hereford district

Lublet

Texline district

Spring Lake district

Measurement of water levels in wells

Fluctuations of water levels in pumping districts

Plainview district

North and northeast of Plainview

East and southeast of Plainview

South and west of Plainview

Summary

Hereford district

North and northeast of Hereford

South and southeast of Hereford

West and southwest of Hereford

Summary

Muleshoe district

East of Muleshoe

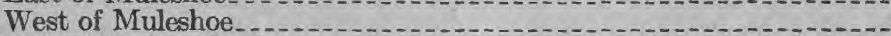

Lubbock-Littlefield district

Texline district

Effect of pumping on ground-water supply

Conclusions

404

404

404

405

406

419

Addendum

421 


\section{ILLUSTRATIONS}

Plate 17. Map of parts of Briscoe, Floyd, and Motley Counties, Tex., showing approximate location of High Plains escarpment and springs below the escarpment.

18. Map of Crosby County and a part of Dickens County, Tex., showing approximate location of High Plains escarpment and springs below the escarpment

19. Map of Plainview district, Tex., showing irrigation, city and town, and observation wells . . In pocket

20. Map of Hereford district, Tex., showing irrigation, city, and observation wells.................. In pocke

21. Map of Muleshoe district, Tex., showing irrigation and obs ervation wells

FIgure 27. Map of High Plains and adjacent region in northwest Texas, showing areas in which most of the irrigation wells are located.

28. Depth to water in wells in areas of ground-water intake, Floyd and Hale Counties, Tex

29. Depth to water in wells near areas of ground-water intake, Lubbock and Deaf Smith Counties, Tex ......................

30. Depth to water in wells in Plainview district, Hale and Floyd

31. Depth to water in wells in Plainview district, Floyd County, Tex. (areas of heavy pumping)

32. Depth to water in wells in Hereford district, Deaf Smith County,

33. Depth to water in wells in Muleshoe district, Bailey and Lamb
Counties, Tex 383

388 389 


\title{
GROUND WATER IN THE HIGH PLAINS OF TEXAS
}

\author{
By W. N. White, W. L. Broadhurst, and J. W. Lang
}

\section{Abstract}

The High Plains of Texas occupy an area of about 35,000 square miles, extending from the northern boundary of the Panhandle southward about 300 miles, and from the New Mexico line eastward an average distance of about 120 miles. This region is divided into two segments by the Canadian River and the name Llano Estacado has usually been assigned by geologists to the southern, or larger part, which is bounded on the east and on the west by the escarpments of the High Plains and on the north by the valley of the deeply entrenched Canadian River. The ground water occurs chiefly in the beds of sand in the Ogallala formation, which underlies the surface throughout almost the entire region and in many places is 200 to 300 feet thick. It rests on an uneven floor of older rocks, which are exposed at the base of the escarpments bounding the High Plains and in the Canadian River Valley. If water is found in them it is generally highly mineralized. As the water-bearing sands of the Ogallala are cut off in all directions by escarpments, they have no underground connections with water-bearing beds outside of the area except through the underlying older rocks, which contain highly mineralized water and could not be the source of the fresh water in the Ogallala. The source of this fresh water, therefore, must be the rain and snow that fall on the surface of the High Plains.

A very large quantity of water, which has accumulated over a long period of time, is stored in the underground reservoir. A small part of this water is discharged each year by the flow of springs, most of which are located along the eastern escarpment or rimrock of the High Plains or along the bluffs on each side of the Canadian River; and by evaporation and the growth of plants in localities on the High Plains where the water table is near the surface. This natural discharge is approximately balanced through a long term of years by water derived from that part of the rainfall upon the area which penetrates to the water table, and this condition of natural equilibrium has not been materially affected by artificial withdrawals from the underground reservoir by pumping. Based on studies of the natural discharge from an area of approximately 9,000 square miles, the annual replenishment over the region is estimated to be a small fraction of an inch, or only a small part of the average annual rainfall.

Irrigation from wells in this region was started more than 30 years ago. The rate of development, which was relatively slow until 1934, has increased greatly in recent years. In 1934 approximately 300 wells were pumped. In 1937, 1,150 wells were pumped and 160,000 acres were irrigated; in 1938, 1,500 wells were pumped and 200,000 acres were irrigated; and in 1939, 1,700 wells were pumped and 230,000 acres were irrigated. On the basis of a partly completed inventory, it is estimated at this writing that about 400 irrigation wells will be put down and equipped in 1940. Most of this development is in 14 counties, the greatest number of wells being in Hale, Floyd, Swisher, Deaf Smith, Castro, Lubbock, Lamb, and Bailey Counties.

Measurements of water levels in a considerable number of wells in the pumping districts of the region.were made and recorded by different State and Federal agencies in 1914, 1934, 1936, and early in 1937. Since the later part of April 1937, in connection with the present investigation, about 600 observation wells have been measured at intervals ranging from a month to a year. Approximately two-thirds of these wells are within or near the pumped areas, the remainder being remote. The measurements indicate that in areas remote from the pumping districts the water levels in general are about the same as they were in 1937. Within or near the pumping districts, however, there has been a general and persistent decline, beginning at least as early as 1934, which ranged from a fraction of a foot to several feet, the greatest decline being in the areas of heaviest pumping. The water that drained out as the water table declined moved downward to replace the pumped water, representing a loss from the volume formerly in storage.

It is concluded that a large part of the water that has been pumped from wells in the High Plains of Texas has been derived by reduction in underground storage. 


\section{INTRODUCTION}

The High Plains of Texas are noted for their abundant supply of ground water. All the water for public and industrial supplies and nearly all that used on farms and ranches comes from wells, and in parts of the region irrigation on a large scale is accomplished with water from wells. It is important that this natural resource should be utilized in such manner as to be of greatest possible benefit for a long time.

Several general investigations of the ground-water resources of the region have been made, and during the past three years a more intensive investigation has been in progress as part of a survey of the ground-water resources of Texas by the Federal Geological Survey in cooperation with the Texas State Board of Water Engineers. Furnishing information periodically on the extent of new ground-water developments, the quantity of water pumped from wells, and the rise or fall of the water levels in the wells is among the purposes of the present investigation. From these data conclusions can be drawn as to the average annual replenishment of the ground-water supply and the quantity of water that is withdrawn each year from natural storage.

The present studies have been made possible through appropriations by the State Legislature and allocations of Federal funds on an equal or nearly equal basis. The field work has been done by W. L. Broadhurst, J. W. Lang, and others, under the direction of Walter N. White, senior hydraulic engineer, and under the general supervision of O. E. Meinzer, geologist in charge of the Division of Ground Water of the Geological Survey.

The statements that follow relate mostly to the source, replenishment, and natural discharge of the ground water; the withdrawal of ground water for irrigation, with special reference to the pumpage during the past three years; the fluctuations of water levels in wells in and near the heavily pumped areas; and the changes that have occurred in recent years in the amount of water in storage within those areas. For convenience most of the discussion of pumpage and water-level fluctuations is given by districts, as follows: Plainview, Hereford, Muleshoe, and Lubbock-Littlefield.

\section{Location and Extent of Area}

The High Plains occupy an area of about 35,000 square miles in Texas, extending from the northern boundary of the Panhandle southward into Glasscock, Ector and Midland Counties, and from the New Mexico line eastward to a boundary, which in most places is sharply defined by a bold escarpment several hundred feet in height. (See fig. 27.) The area is roughly rectangular in shape, averaging about 300 miles from north to south and 120 miles from east to west. It is divided into two segments by the Canadian River, and the name Llano Estacado has usually been assigned by geographers and geologists to the larger, southern part. In popular usage the Panhandle is called the North Plains and the remainder the South Plains.

\section{ACKNOWLEDGMENTS}

Acknowledgments are made to the Plainview office of the Texas Land \& Development Co. for free access to the company's records; to Harry P. Burleigh and others of the Bureau of Agricultural Economics of the United States Department of Agriculture for their cooperation and 


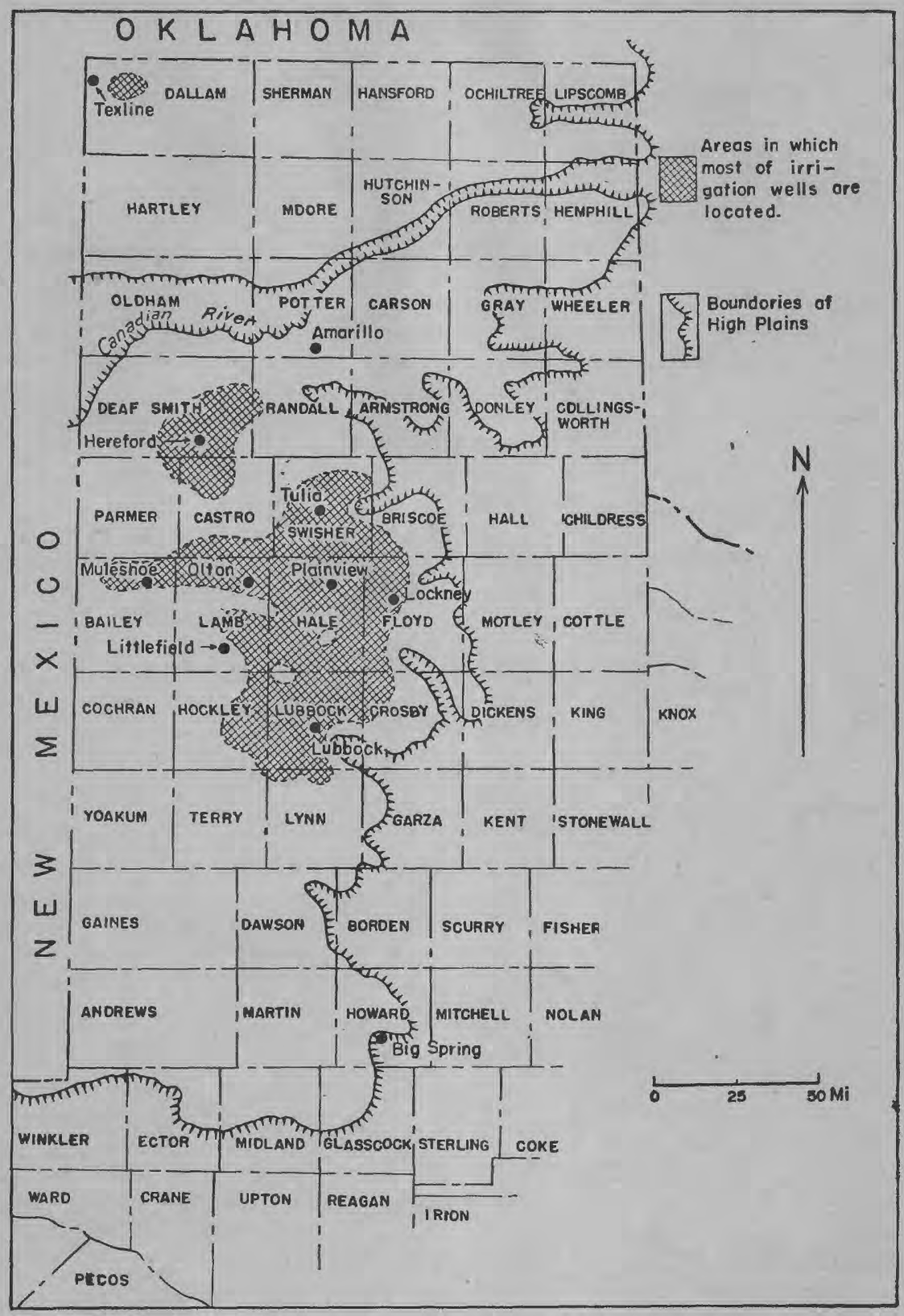

Frauke 27.-Map of High Plain and adjacent region in northwest Teras, showing areas in whloh most of the Irrigatlon wells are located.

general information; to State Representative A. B. Tarwater for his unfailing interest and cooperation; to district representatives of the various pump companies for information on well-drilling methods and 
new well development; and to many well owners and operators throughout the High Plains for valuable information about their wells and pumping plants. Acknowledgment is also made to ranchers for free access to lands and for information about the location of springs along the escarpment.

\section{Previous Ground-Water Investigations}

W. D. Johnson ${ }^{1}$ spent several years on the High Plains just prior to 1900 and published his findings, relating in part to the ground-water resources, in the 21st and 22d Annual Reports of the Federal Geological Survey. The geology and ground-water resources of the northern 20 counties of the Texas Panhandle were studied by C. N. Gould in 190405. ${ }^{2,3}$ In 1909, O. E. Meinzer made a brief study of ground-water on the High Plains in Portales Valley, N. Mex. C. L. Baker ${ }^{5}$ of the Texas Bureau of Economic Geology made a study of the geology and hydrology of a part of the region in 1914. His report contains two chapters on ground water and tables of water-well logs and water analyses, including information on the depth to water in a considerable number of wells, partly determined by measurements.

A study of ground water on the High Plains near Portales, N. Mex., has been in progress since 1931 under the direction of C. V. Theis of the Federal Geological Survey, and the results have been published in the biennial reports of the State Engineer of New Mexico. ${ }^{6}$ A reconnaissance investigation of ground water in the High Plains of Texas and also of Kansas, Colorado, New Mexico, and Oklahoma was made by C. V. Theis, H. P. Burleigh, and H. A. Waite in 1933-34. In this investigation a large amount of preliminary data was obtained, including well records and measurements of water levels in wells, of which several were located in each of the pumping districts discussed in this report. A summary of the results is given in a memorandum for the press. ${ }^{7}$ A study of wells and irrigation with water from wells was made in 1936 by geologists and engineers of the Resettlement Administration in several localities in the High Plains, including the Plainview, Hereford, and Muleshoe pumping districts, The field work included measurements of static water levels in a considerable number of wells in each pumping district, the records of which have been available for study in the present investigation.

During the years 1936 to 1939 , inclusive, inventories of water wells were made in all parts of 25 counties of the High Plains under an allocation of funds by the Work Projects Administration. This project is sponsored by the State Board of Water Engineers and has been carried out with the assistance of the Federal Geological Survey under the direction of S. F. Turner and W. O. George and with the Bureau of Industrial Chemistry of the University of Texas under the direction of

\footnotetext{
1 Johnson, W. D., The High Plains and their utiliastion: U. S. Geol. Survey, 21st Ann. Rept., pt. 4, Hydrog aphy, pp. $602-741$, 1901; 22d Ann. Rept., pt. 4, Hydrography, pp. 637-669, 1902.

8 Gould, C. N., The geology and water resources of the eastern portion of the Panhandle of Texas: U. S. Geol. Survey Water-Supply Paper 154, 1906.

3 Gould, C. N., The geology and water resources of the western portion of the Panhandle of Texas: U. S. Geol. Survey Water-Supply Paper 191, 1907.

4 Meinser, O. E., Ground-water resources of Portales Valley, N. Mex. (manuscript report in files of U. S. Geol. Survey, Washington, D. C.).

5 Baker, C. L., Geology and underground waters of the Northern Llano Estacado: Univ. Texas Bull. 57, 1915.

6 Theis, C. V., Report on ground water in Curry and Roosevelt Counties, N. Mex.: New Mexico State Eng. 10th Bienn, Rept., 1930-32, pp. 99-160 [1933]. Progress report on ground-water supply of Portales Valley, N. Mex.: New Mexico State Eng. 11th Bienn. Rept., 1932-34, pp. 87-108 [1935]. Progress report on ground-water supply of Portales Valley, N. Mex.: New Mexico State Eng. 12th and 13th Bienn. Repts., 1934-38, pp. 101-119 [1939].

7 Theis, C. V., Burleigh, H. P., and Waite, H. A., Ground water in the Southern High Plains: U. S. Geol. Survey memorandum for the press, Det. 30, 1035. [Mimeographed.]
} 
Dr. E. P. Schoch. The counties partly or fully covered by the inventories are Andrews, Armstrong, Bailey, Carson, Castro, Crosby, Dallam, Ector, Floyd, Glasscock, Hale, Hansford, Hartley, Hockley, Howard, Lamb, Lubbock, Martin, Midland, Ochiltree, Oldham, Parmer, Potter, Randall, and Roberts. The well inventories in Dawson, Deaf Smith, and Swisher Counties and parts of Hale and Floyd Counties were made by employees of the Texas Board of Water Engineers in connection with the regular cooperative program. Mimeographed bulletins giving tables of well records, well logs, and water analyses, together with a map showing the location of the wells, have been issued for all these counties.

A progress report ${ }^{8}$ summarizing the results of the present investigation to May 1938 was published on July 26, 1938, and a brief summary of the outstanding results to March 1939 was released on April 12, 1939. The results of water-level measurements in wells in the High Plains and other parts of Texas to December 31, 1939, are given in Water-Supply Papers 840,845 , and 886 of the Federal Geological Survey. 10,11,12 Copies of the water-well inventories, progress report, and press release have been distributed to most colleges, high schools, public libraries, and chambers of commerce in the High Plains of Texas, and several hundred copies of the progress report of 1938 have been distributed to individual property owners.

The present report, which gives the most important results obtained from the investigation to April 1, 1940, includes records of water levels in observation wells obtained in July and November 1940 and a brief statement on the number of new wells completed and the decline of water levels to November 18, 1940.

\section{SOURCE OF THE GROUND WATER}

Most of the usable ground water in the High Plains is found in the Ogallala formation, a sandy deposit, in many places 200 to 300 feet thick, lying at or near the surface throughout almost the entire region. The formation is composed of silt and fine sand, with some coarse sand and gravel. The coarser sediments, which usually yield water freely to wells, are present at all horizons but are most prominent in the lower part of the formation. They were deposited by streams, some of which had their headwaters in the Rocky Mountains, and by wind. The Ogallala rests on an uneven floor of older rocks, which was eroded into valleys and ridges before the Ogallala was deposited. Nearly everywhere in the High Plains the water in these underlying rocks is highly mineralized and unfit for most uses.

The beds of the Ogallala formation once extended from the mountains of New Mexico eastward far into Texas, but they have been removed by erosion from much of the territory they once occupied. The areas in which this formation is still present stand up almost like islands, being bounded by the escarpments of the High Plains, both on the east and on the west, and being separated in Texas by the Canadian River, which is deeply entrenched in the older rocks. The Ogallala formation has been completely eroded away west of the western escarpment and

\footnotetext{
B White, W. N, Broadhurst, W. L., and Lang, J. W., Ground water in the High Plains in Texas, Texas State Bd. Water Eng. July 26, 1938. [Mimeographed.]

9 Ground water in the Texas High Plains: Texas State Bd. Water Eng. press release, Apr. 12, 1939. [Mimeographed. 10 Meinzer, O. E., and Wenzel, L. K., Water levels and artesian pressure in wells in the United States in 1937 (Texas section by S. F. Turner): U. S. Geol. Survey Water-Supply Paper 840, 1938.

11 Meinzer, O. E., and Wenzel, L. K., Water levels and artesian pressure in wells in the United States in 1938 (Texas section by S. F. Turner); U. S. Geol. Survey Water-Supply Paper 845, 1939.

12 Meinzer, O. E, and Wenzel, L. K. Water levels and artesian pressure in wells in the United States in 1939 (Texa Bection by R. W. Sundstrom): U. S. Geol. Survey Water-Supply Paper 886, 1940 [1941].
} 
east of the eastern one and from the canyonlike valley of the Canadian River. The water-bearing sands and gravels of the Ogallala in both of these segments, therefore, are cut off in all directions from any underground connection except through the underlying older rocks, which contain highly mineralized water entirely unlike the fresh water in the Ogallala.

In parts of the High Plains, wells in the Ogallala yield large quantities of water and in some localities many such wells have been used for years. It is not surprising therefore that a popular theory has developed to the effect that the wells are tapping an inexhaustible supply of water in an underground river which flows beneath the High Plains and has its source in the Rocky Mountains far to the west. As a matter of fact the high yield of the wells is explained by the relatively high permeability of the sands and gravels from which they draw water. The water is contained in interstices between the particles of gravel and grains of sand. Although it is moving, generally in a southeasterly direction, the movement is very slow, perhaps at an average rate of 200 to 300 feet a year, and therefore is scarcely comparable to that of a river. Inasmuch as the water-bearing beds are cut off in all directions from outside sources of water except through underlying rocks containing poor water, it follows that the source of the fresh water must be entirely within the High Plains area and must be the rain and snow that fall on its surface.

Most of the precipitation is dissipated through evaporation or through transpiration by grasses, shrubs, and cultivated crops, but some runs off and a small part moves downward to the underground reservoirs by direct penetration or by seepage from streams and depression ponds.

\section{RECHARGE OF GROUND WATER}

Most of the surface of the High Plains is underlain by sediments that are cemented with calcium carbonate and usually called caliche. These deposits probably prevent deep penetration of surface water over most of the High Plains. In places, however, the caliche is thin or has been partly removed by solution, and in such areas the water may move downward to the water table. The principal areas of ground-water recharge apparently are depressions occupied by intermittent ponds; sandy stream beds and adjacent sandy flood plains; and sand-dune areas.

\section{Recharge From Depression Ponds}

Depressions, or sinks, ranging from a few feet to 50 feet or more in depth, and from a few hundred feet to a mile or more in diameter, are of common occurrence in the Texas High Plains. In some areas these depressions average as much as one to each square mile. During heavy rains, ponds that range in area from a few acres to 100 acres or more are formed in the depressions. Some of the ponds disappear in a short time, others remain for months. Several hundred test holes have been drilled in the beds of depression ponds on the High Plains in connection with the present investigation. These holes were drilled to an average depth of about 30 feet and spaced 100 to 300 feet apart in lines across the depressions. A few were drilled to a depth of about 100 feet. In some of the depressions relatively little caliche was encountered, in others caliche was found all the way across but was relatively soft, and in still others the caliche was so hard it could not be penetrated by the hand drill and was designated by the drillers as rock. In areas where the 
caliche was absent the sediments penetrated in many of the holes were relatively permeable from the surface to the bottom of the hole. Graphic cross sections illustrating the character of material encountered in some of the test holes are shown in several of the county well inventories.

The bottom of most of the depressions is covered with deposits of silt and soil, in places resembling gumbo and ranging from 2 to 10 feet in thickness. After the ponds become dry, fractures and crevices several feet in depth frequently develop in their beds. In some of the depressions small sinks, apparently developed by solution channeling in the underlying caliche deposits, are present. These crevices and solution channels may provide a pathway for the downward movement of water for a time after the ponds are filled, although they may become sealed after water has stood over them for several days. The bottom area of most of the depressions is usually surrounded by a sandy belt, which absorbs water readily. Gages were placed in several of the ponds during the summers of 1937 and 1938, and the rate of decline of the water levels was observed at regular intervals for several months. In some of the ponds the rate of decline was small and apparently was due mostly to losses from evaporation. In others it was at first quite rapid, amounting in some cases to 2 inches or more a day for 10 days or so after the rains, and then gradually slowed down.

A considerable number of the observation wells are near intermittent ponds, and most of them show a rise in water levels after heavy rains have filled the ponds. The fluctuations of water levels in five widelyspaced wells near depression ponds in Hale, Floyd, Lubbock, and Deaf Smith Counties are shown graphically in figures 28 and 29.

\section{Recharge From Streams}

The streams that head in the High Plains are intermittent or ephemeral. After exceptionally heavy rains these streams carry large quantities of water, but generally only a comparatively small part of the water reaches the eastern escarpment or rim of the High Plains. For example, after heavy rains in May 1937, the discharge of Running Water Draw at Plainview reached a peak of about 1,200 second-feet but the maximum flow 15 miles below Plainview was only about 80 second-feet. Apparently nearly all the water was absorbed by the soil, and a part percolated downward to the water table. Again, rains of almost cloudburst intensity fell in western Bailey County near the head of Blackwater Draw in June 1938, but no water flowed in the draw in Lamb County, 30 miles to the east. Other examples also could be cited, if space permitted.

The two lower graphs in figure 28 show fluctuations of water levels that occurred in wells 402 and 511 in Hale County in response to intermittent flows of storm water in Running Water Draw. The records are not continuous and therefore the graphs probably do not show the maximum variations in the levels during the period. Numerous observation wells near streams in other parts of the area have shown a substantial rise in water level after freshets.

\section{Recharge in Sand-Hill Areas}

Sand dunes of wide extent occur in parts of the High Plains. They produce a rolling topography of low hills and ridges with intervening valleys of varying widths. Nearly all the rain that falls on the dune- 
covered areas is absorbed by the sand and on that account no lines of drainage, or only meager ones, have been developed. These conditions are favorable for ground-water recharge, and the sand-dune areas generally are believed to be among the best collecting areas for ground

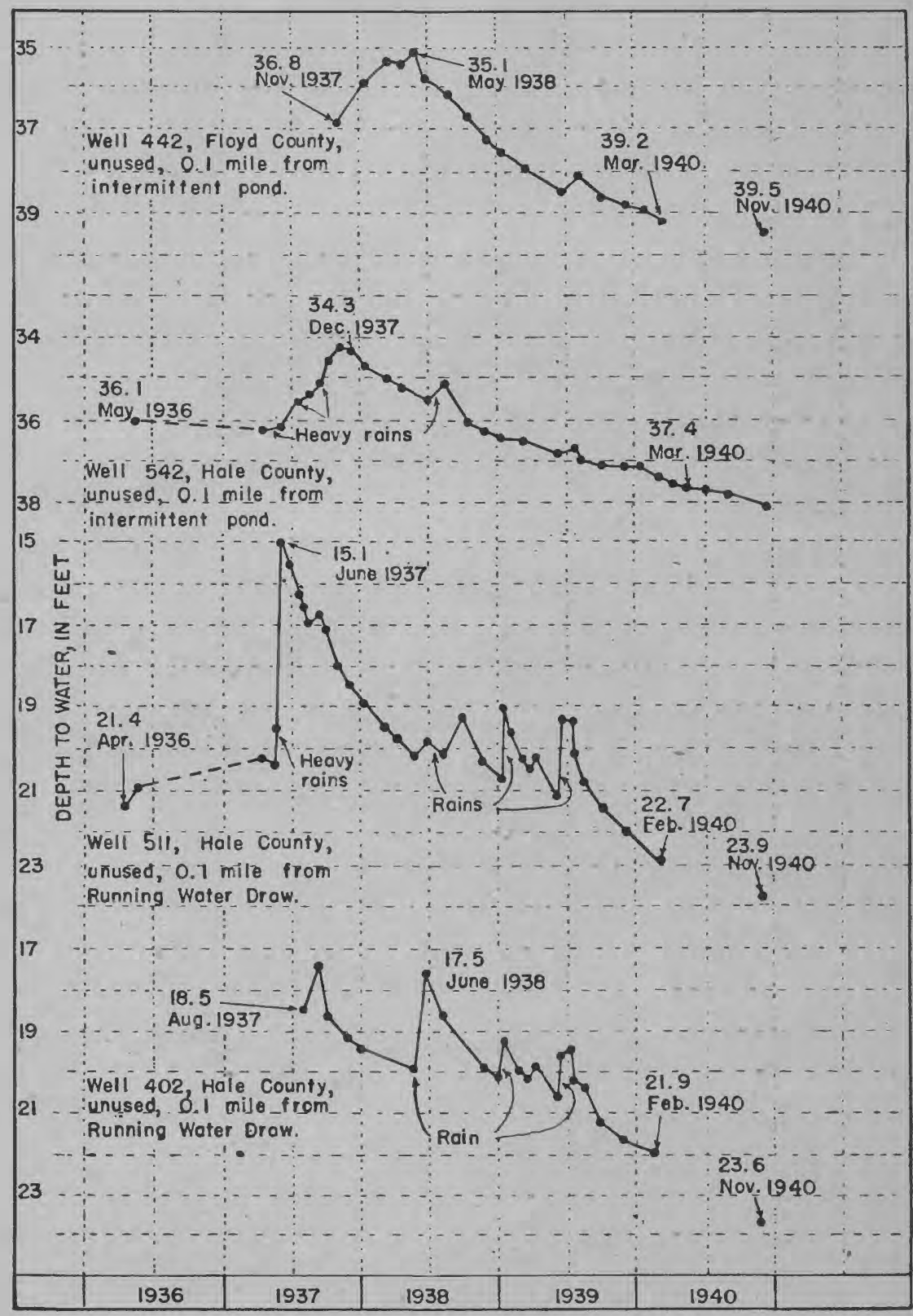

- Measurements recorded in tables of water-level fluctuations.

Frgurm 28.-Depth to water in wells in areas of ground-water intake, Floyd and Hale Counties, Tex. 
water in the Texas High Plains. Considerable evidence of this already has been obtained, and the subject is still under study. Among the largest of the sand-dune areas is one that extends eastward from Roosevelt County, N. Mex., across Bailey and Lamb Counties and a part of

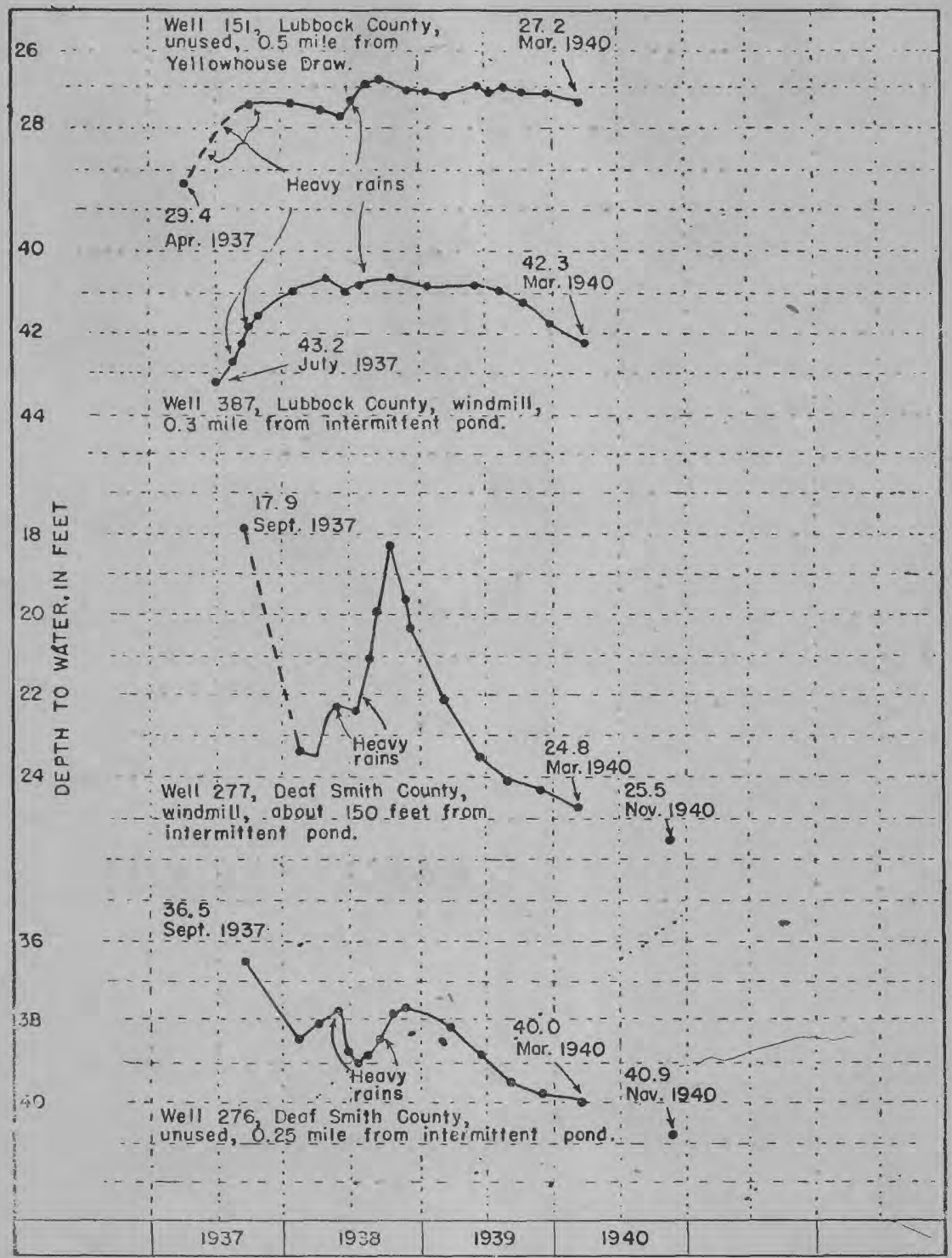

- Meosurements recorded in tables of water-level fluctuations.

Fiqung 29,-Depth to water in wells near areas of ground-water intake, Lubbock and Deaf Smith Counties, Tex.

Hale County, Tex. Sand-dune areas of varying extent also cover parts of Yoakum, Terry, Lynn, Dallam, Hartley, Oldham, and other counties of the region. 


\section{NATURAL DISCHARGE OF GROUND WATER}

Before pumping was started, the ground-water reservoirs of the High Plains were in a state of approximate equilibrium. The average annual recharge was balanced by an approximately equal average annual discharge. The greater part of the natural discharge occurred through springs and seeps along the eastern escarpment of the High Plains and along the bluffs on either side of the Canadian River. A part of the water was discharged by evaporation and the transpiration of trees, grasses, and shrubs in shallow water-table areas on the High Plains, and a small amount was lost by evaporation from water-table lakes.

\section{Discharge of Ground Water From Escarpment Springs and Seeps}

Most of the springs along the escarpment, or rimrock, appear at or near the contact between the water-bearing sands and gravels and the underlying older clays and shales. They generally occur in the ravines and canyons, and in places give rise to streams of considerable size. In some places where the sands and gravels rest directly on older sandstone or conglomerate, the water issues from joints, fractures or solution channels in those rocks. The greater part of the springs occur within 1 to 3 miles of the top of the escarpment but a few, most of them small, appear along the streams at greater distances. An outstanding exception is Roaring Springs, in Motley County, which issues from conglomerate about 9 miles to the east of the escarpment and has a comparatively large discharge.

In 1938-39, studies of ground-water discharge were made along a 75-mile stretch of the escarpment extending southward from Quitaque Creek to Double Mountain Fork of the Brazos River across parts of Briscoe, Floyd, Motley, Dickens, and Crosby Counties. This survey sccupied the time of two or three men for several weeks. All known springs and seeps were visited and the more important ones were mapped. (See pls. 17 and 18.) The discharge of the springs and seeps was measured or estimated, and the losses of ground water by evaporation and transpiration, not taken into account in the measurements, were estimated. From these data the total discharge of ground water along the 75 -mile stretch of the escarpment was estimated as about 12,000 gallons a minute, or around 17 million gallons a day. This is the equivalent of about 53 acre-feet a day or about 19,000 acre-feet a year.

\section{Discharge of Ground Water in Shallow Water-Table Areas on the High Plains}

In connection with the investigation along the escarpment a study was made of ground-water discharge in a part of the High Plains comprising about 9,000 square miles and extending approximately 120 miles to the northwest from the 75-mile stretch of the escarpment described in the preceding section. This is in the up-slope direction of the water table. The greater number of irrigation wells in the High Plains are in this area.

Some natural discharge occurs here by evaporation from ponds in deep depressions. These ponds are fed in part by surface water and in part by ground water and on this account the amount of ground water discharged from them can not be accurately computed. The total discharge, however, is believed to be relatively small. Most of the ground-water discharge in the territory occurs in shallow water-table 
areas along the Double Mountain Fork of the Brazos River, Running Water Draw, and Tierra Blanca Creek. In the western and middle parts of the High Plains these streams carry storm water only. Farther east near the escarpment where they have cut deep canyonlike valleys, in places to a level below the water table, they have small perennial flows of spring water. This water was taken into account in the computations of spring discharge along the escarpment. In numerous places along these streams ground water in considerable quantities is consumed by the growth of marsh grasses and sedges, subirrigated alfalfa, salt grass, and various meadow grasses, and by trees of which cottonwood and willow are the most common.

During the summers of 1937, 1938, and 1939 the lands covered by the different kinds of grasses and subirrigated alfalfa that use ground water were roughly mapped, and estimates were made of the amount they consume annually, in acre-feet to the acre. Marsh grasses and sedges probably use most water to the acre. Subirrigated alfalfa probably comes next, but in most places it has a rather light growth and apparently is using considerably less water than irrigated alfalfa in the adjacent territory. The salt grass and meadow grasses have a rather dense growth in places, but on the average the stand is light and the consumption of ground water probably small. Considerable loss occurs from evaporation in fields of marsh grasses and sedges, but in other areas the loss is small. Estimates are given below of the total number of acres in the area that are covered by the different kinds of ground-water-using grasses and alfalfa, and the total amount of ground water in acre-feet consumed annually by each kind. About 3,000 trees, mainly cottonwoods and willows, were counted in the bottom lands of the area, but no effort was made to compute the amount of ground water that they use.

Estimates of discharge of ground water by transpiration from area of 9,000 square miles

\begin{tabular}{|c|c|c|c|}
\hline & $\begin{array}{c}\text { Number of } \\
\text { acres }\end{array}$ & $\begin{array}{l}\text { Fstimated depth } \\
\text { of water } \\
\text { consumed } \\
\text { (feet) }\end{array}$ & $\begin{array}{c}\text { Total } \\
\text { (acre-feet) }\end{array}$ \\
\hline $\begin{array}{l}\text { Marsh grass and sedges } \\
\text { Subirrigated alfalfa. } \\
\text { Salt grass and other grasses.. } \\
\text { Trees. }\end{array}$ & $\begin{array}{r}500 \\
500 \\
12,000 \\
\end{array}$ & $\begin{array}{l}3 \\
1.5 \\
.5\end{array}$ & $\begin{array}{l}1,500 \\
750 \\
6,000\end{array}$ \\
\hline Total.. & , & - & 8,000 \\
\hline
\end{tabular}

\section{Total Natural Discharge From the Area}

From the measurements and estimates described above, the total natural discharge of ground water from the area has been estimated to be at the rate of 25,000 to 30,000 acre-feet a year, representing only a small fraction of an inch over 9,000 square miles of the area.

\section{HISTORY OF THE DEVELOPMENT OF GROUND WATER FOR IRRIGATION}

Irrigation from wells in this region was started more than 30 years ago near Portales, N. Mex., situated on the High Plains about 15 miles west of the Texas-New Mexico boundary. The development soon spread to nearby areas in Texas. According to an early issue of a Plainview 
paper, the first successful irrigation well in that area was drilled on the farm of J. H. Slaton 4 miles west of Plainview in January 1911. During that year 6 or 7 additional irrigation wells were put down, and in 1912 Dr. Frederick Pearson, of New-York, organized a syndicate known as the Texas Land and Development Co., purchased 60,000 acres of land near Plainview, and started the development of ground water on a large scale. By 1913 the syndicate had drilled and equipped 85 irrigation wells.

In the report of his investigation in 1914, Baker $^{13}$ lists 139 irrigation wells in the High Plains of Texas, as follows: 100 in the general vicinity of Plainview, in eastern Hale County, western Floyd County and southern Swisher County; 27 near Hereford, in southeastern Deaf Smith County; and 12 near Muleshoe, in northeastern Bailey County and northwestern Lamb County.

According to records of the Texas Land and Development Co., there were 160 irrigation wells in the Plainview district in 1918, of which 127 had been equipped by the company and 33 by individual landowners.

During the World War there was a general decline in well-water irrigation, owing in part to the shortage and high cost of labor, and in part to the introduction of the tractor, which encouraged cultivation and cropping of large tracts by dry-farming methods. In the 7 years following the war, 1919 to 1926, the rainfall in most of the region was above average and comparatively little irrigation was practiced. Interest was revived during a period of several years of low rainfall which began with 1927. According to Theis, there were 296 irrigation wells in the Texas High Plains in 1934, of which 180 were located in the Plainview district, 70 in the Muleshoe district, and 46 in the vicinity of Hereford. The rate of development, which had been relatively slow to 1934, increased materially in 1935. It was accelerated to some extent in 1936 and became still more rapid in 1937, but the rate of increase declined somewhat in 1938 and 1939. Some of the wells put down from 1935 to 1939 were located in the older pumped areas, but many were drilled in new territory. Briefly summarized, the construction and equipping of irrigation wells occurred about as follows: 1911 to 1914 , inclusive, 139 wells; 1915 to 1934,157 wells; 1935 and 1936 , approximately 300 wells; 1937, 550 wells; 1938, 350 wells; and 1939, 200 wells.

\section{USE OF GROUND WATER FOR IRRIGATION, 1937-39}

In order to estimate the amount of water that is being withdrawn from the underground reservoirs of the High Plains, the record of new irrigation weils has been kept as nearly up to date as practicable, and each year since 1937 complete or partial inventories have been made of the amount of land under irrigation and the amount of water applied to the land. In 1937, practically every pumping plant in the territory was visited and the owner or pump operator interviewed in regard to its use during the season. In most cases information could be obtained regarding the number of acres irrigated from the well, the length of time required to water each field and the number of times it was watered during the year, but only a few of the operators knew the yield of their pumps or had kept records of the total number of hours the pumps were operated during the season. During the preceding year (1936), however, engineers of the Resettlement Administration had measured

\footnotetext{
18 Baker, C. L., Geology and underground waters of the Northern Llano Estacado: Univ. Texas Bull. 57, 1916.
} 
the yield of about 65 representative wells in the Plainview, Hereford, and Muleshoe pumping districts, some of the wells belonging to farmers who had kept systematic records of the operations of their pumps. The results of the Resettlement measurements were made available, and from this information and the farmers' records of pumping operations, estimates were made of the average depth of water applied during the season to each kind of crop. From these estimates and data obtained in the field as to the number of acres that were irrigated in each kind of crop, estimates were made of the total amount of water pumped in each district.

In 1938 and 1939 only a part of the irrigation wells were visited. From 10 to 15 percent of the wells in each district were selected for study, and during the two pumping seasons the yield of about 100 wells was measured with a weir or current meter. Daily records of pumping operations were obtained for some of the wells, including records gathered by the office of the United States Bureau of Agricultural Economics, which were made available. Records were kept of practically all new irrigation wells and old wells not in operation.

Estimates are given below of the number of wells pumped for irrigation, by counties and by districts, and the number of acres irrigated in each district in 1937, 1938, and 1939.

Estimated number of wells pumped for irrigation, by counties, in High Plains of Texas in 1937, 1988, and 1989

\begin{tabular}{|c|c|c|c|}
\hline County & 1937 & 1938 & 1939 \\
\hline $\begin{array}{l}\text { Bailey } \\
\text { Briscoe } \\
\text { Castro } \\
\text { Crasby. } \\
\text { Dallam } \\
\text { Deal Smith } \\
\text { Floyd. } \\
\text { Hale } \\
\text { Hockley. } \\
\text { Lamb } \\
\text { Pubbock } \\
\text { Rarmer } \\
\text { Swisher } \\
\text { Others }\end{array}$ & $\begin{array}{r}70 \\
10 \\
50 \\
8 \\
13 \\
130 \\
230 \\
280 \\
28 \\
100 \\
100 \\
5 \\
6 \\
120 \\
\end{array}$ & $\begin{array}{r}78 \\
13 \\
90 \\
10 \\
25 \\
182 \\
250 \\
330 \\
30 \\
130 \\
155 \\
5 \\
10 \\
180 \\
12\end{array}$ & $\begin{array}{r}95 \\
15 \\
100 \\
10 \\
25 \\
200 \\
265 \\
375 \\
36 \\
150 \\
190 \\
6 \\
10 \\
200 \\
23\end{array}$ \\
\hline Total. & 1,150 & 1,500 & 1,700 \\
\hline
\end{tabular}

Estimated number of wells pumped for irrigation and total amount of land irrigated from them, by districts, in High Plains of Texas in 1987, 1938, and 1939

\begin{tabular}{|c|c|c|c|c|c|c|}
\hline \multirow[b]{2}{*}{ District } & \multicolumn{2}{|c|}{1937} & \multicolumn{2}{|c|}{1938} & \multicolumn{2}{|c|}{1939} \\
\hline & $\begin{array}{c}\text { Wells } \\
\text { pumped }\end{array}$ & $\begin{array}{c}\text { Acres } \\
\text { irrigated }\end{array}$ & $\begin{array}{l}\text { Wells } \\
\text { pumped }\end{array}$ & $\begin{array}{c}\text { Acres } \\
\text { irrigated }\end{array}$ & $\begin{array}{c}\text { Wells } \\
\text { pumped }\end{array}$ & $\begin{array}{c}\text { Acres } \\
\text { irrigated }\end{array}$ \\
\hline $\begin{array}{l}\text { Plainview } \\
\text { Hereford } \\
\text { Lubbock-Littlefield_. } \\
\text { Muleshoe } \\
\text { Spring Lake_. } \\
\text { Texline } \\
\text { Other wells }\end{array}$ & $\begin{array}{r}630 \\
170 \\
170 \\
90 \\
45 \\
13 \\
32\end{array}$ & $\begin{array}{r}100,000 \\
33,000 \\
17,000 \\
6,300 \\
3,700\end{array}$ & $\begin{array}{r}790 \\
240 \\
250 \\
100 \\
63 \\
25 \\
32\end{array}$ & $\begin{array}{r}115,000 \\
40,000 \\
23,000 \\
5,500 \\
16,000\end{array}$ & $\begin{array}{r}855 \\
260 \\
310 \\
125 \\
87 \\
25 \\
38\end{array}$ & $\begin{array}{r}130,000 \\
40,000 \\
30,000 \\
12,000 \\
18,000\end{array}$ \\
\hline Total. & 1,150 & 160,000 & 1,500 & 200,000 & 1,700 & 230,000 \\
\hline
\end{tabular}


The total amount of water, in acre-feet, withdrawn from the underground reservoir during the period is roughly estimated as follows: $1937,130,000 ; 1938,145,000 ; 1939,165,000$.

The irrigation development is discussed below by districts, which have been arbitrarily bounded to include counties or parts of counties as follows: Plainview district-Hale, Floyd, Swisher, and Briscoe Counties; Hereford district-Deaf Smith County and northwestern part of Castro County; Muleshoe district-Bailey County and northwestern part of Lamb County; Lubbock-Littlefield district-Crosby, Lubbock and Hockley Counties and southeastern part of Lamb County; Spring Lake district-northeastern part of Lamb County and southern part of Castro County; Texline district-Dallam County. Occasional irrigation wells are found in different parts of the High Plains outside of these districts but the total number is small. Most of the irrigation wells put down prior to the spring of 1939 in the Plainview, Hereford, and Muleshoe districts are shown on plates 19-21.

\section{Plainview District}

In the Plainview district in 1937 approximately 630 wells were pumped for irrigation and 100,000 acres of land were irrigated from them; in 1938, 790 wells were pumped and 115,000 acres were irrigated; in 1939,855 wells were pumped and 130,000 acres were irrigated. About 200 were drilled before 1935, 190 in 1935 and 1936, 250 in 1937, 150 in 1938, and 65 in 1939. The estimated average depth of water applied to the land; usually expressed in acre-feet to the acre, was about as follows: 1937, 0.8 foot; $1938,0.8$ foot; $1939,0.75$ foot. The locations of about 600 of the irrigation wells are shown on plate 19.

\section{Hereford District}

In the Hereford district in 1937 about 170 wells were pumped and 33,000 acres were irrigated; in 1938,240 wells were pumped and 40,000 acres were irrigated; in 1939, 260 wells were pumped and 40,000 acres were irrigated. About 40 of the wells pumped in 1939 were drilled prior to 1935,30 wells were drilled in 1935 and 1936,100 in 1937,70 .in 1938, and 20 in 1939. About 80 percent of the wells in the district are within an area of 270 square miles centering around Hereford. The area of heaviest pumping comprises about 100 square miles within a few miles of the town, where there is an average of one well to each square mile. The average depth of water applied for irrigation in the district is estimated as about 0.8 foot in 1937, 0.65 foot in 1938, and 0.8 foot in 1939.

\section{Muleshoe District}

In the Muleshoe district about 125 wells were pumped for irrigation - in 1939. Of these, about 56 were drilled or dug before 1935, 20 in 1935 and 1936, 12 in 1937, 12 in 1938, and about 25 in 1939. Most of the wells are in a rectangular-shaped area, about 20 miles long from east to west and 3 to 4 miles wide, in which there is an average of one well to about 400 acres.

Approximately 6,300 acres were irrigated in the district in 1937, 5,500 acres in 1938, and 12,000 acres in 1939. The average depth of water applied for irrigation is estimated as about $0.9,1.0$ and 0.7 acre-foot per acre in the 3 years, respectively. 


\section{LubBock-LitTLEField District}

Approximately 310 wells were being pumped for irrigation in the Lubbock-Littlefield district by the end of 1939 . The wells are located in an irregularly-shaped area comprising about 800 square miles, and, in general, are rather widely spaced, the heaviest pumping being in the vicinity of Lubbock and in the territory between Lubbock and Littlefield. About 20 of the wells were drilled before 1935, 150 in 1935, 1936, and 1937, 80 in 1938, and 60 in 1939.

It is estimated that approximately 17,000 acres were irrigated in the district in 1937, 23,000 acres in 1938, and 30,000 acres in 1939. The average depth of water applied for irrigation apparently was around 0.6 foot, 0.6 foot, and 0.65 foot for the 3 years, respectively.

\section{Texuine District}

Approximately 25 wells are equipped with pumping plants in the Texline district in northwestern Dallam County. The first wells were drilled about 1932, but most of the development has taken place since 1936. No detailed records are available to indicate the number of acres under irrigation. The tendency in this locality is to water smaller tracts of land from each well than is the case in most irrigated districts in the Texas High Plains.

\section{Spring Lake District}

There are 87 wells in the Spring Lake district, practically all of them drilled since the spring of 1936 . The average number of acres irrigated from each well in the district is comparable to that in adjoining areas to the north and east.

A few wells in other parts of the Texas High Plains are pumped to irrigate small tracts of land.

\section{MEASUREMENT OF WATER LEVELS IN WELLS}

The water levels in wells are nearly always rising or falling in response to varying influences, among which changes in the rate of ground-water intake or recharge and in the withdrawal of water through wells are the most important. Measurements of water levels in a considerable number of wells in the High Plains of Texas were made and recorded by State and Federal agencies in 1914, 1934, 1936, and in March 1937. Since the later part of April 1937 the water levels in about 600 observation wells in the region have been measured at intervals ranging from a month to a year as part of the present program of investigation. The records of measurements in 200 wells are given on pages 407-418.

The observation wells are irregularly spaced from the vicinities of Big Spring, Stanton, and Midland, northward to Oklahoma, and from the eastern escarpment of the High Plains to New Mexico. Approximately two-thirds of them are within or near areas in which well irrigation of varying degrees of magnitude is being carried out, the remainder being remote. Some of the observation wells in both irrigated and nonirrigated districts are near streams or depression ponds or among sand hills, where conditions are favorable for the intake of water, and some are on the uplands, where such topographic influences are absent. The observation wells have been carefully selected for the purpose of obtaining information on the location of areas of ground-water intake, the 
amount of intake, and the effect that pumping has on the ground-water supplies. Where they are available, unused wells have been selected for observation, because the water levels in them are undisturbed by the effect of pumping, and where such wells remain open they indicate the static level of the water table more accurately than do used wells. In some cases, however, an unused well becomes partly filled up or the screens become clogged and the water level fails to indicate the true position of the water table. Approximately one-third of the observation wells are unused. Some of them are pumped for irrigation and some are equipped with a windmill or hand pump and used for domestic purposes and for stock. Wells with a pumping plant or windmill are measured only when the pumps are idle and when practicable the wells are shut down for several hours before a measurement is taken. In the irrigation districts as many measurements as practicable are made late in fall and winter, when most of the pumping plants are shut down for the season. The measurements of depth to water are made with a steel tape from a fixed reference point at or near the top of the well.

As previously mentioned, the water-level measurements to December 31,1939 , are published in Water-Supply Papers 840,845 , and 886 of the Geological Survey.

\section{FLUCTUATIONS OF WATER LEVELS IN PUMPING DISTRICTS}

In heavily pumped districts records of the water levels in wells and of the amount of water withdrawn from wells over a period of years, when studied together and properly interpreted, give the best available information regarding the safe yield of the underground reservoirs. Baker ${ }^{14}$ gives the depth to water below the land surface, as recorded in the winter of 1913-14, in approximate:y 100 wells of the Plainview, Hereford, and Muleshoe districts. He obtained his information mostly from reports of well owners, but a few of the wells were measured, of which about 25 are included among the present observation wells. The water levels in 27 of the observation wells were measured by Theis and party in 1934, of which 14 are in the Plainview district, 5 in the Hereford district, and 8 near Muleshoe. Engineers of the Resettlement Administration measured the depth to water in 130 of the observation wells in April, May, and June 1936 and made measurements in 18 of them in March 1937. The present well-measuring program was started in the latter part of April 1937. Considerable pumping had been done previous to the spring measurements, both in 1936 and 1937, and the water table had probably declined considerably before the measurements were made.

Records of the measurements in most of the observation wells in the Plainview, Hereford, and Muleshoe pumping districts are given on pages 407-418 of this report. A description of most of the observation wells has been published in the water-well inventory report for Hale, Floyd, Swisher, Deaf Smith, Castro, Lamb, and Bailey Counties, copies of which are on file at offices of the chambers of commerce and country officials, and at many of the college, high school, and city libraries throughout the High Plains. A few copies of these county reports are available for distribution and may be obtained from the Texas Board of Water Engineers, Austin, Tex. The hydrographs in figures 30 to 33

14 Baker, C. L., Geology and underground waters of the Northern Llano Estacado: Univ. Texas Bull. 57, 1916. 
show graphically the water-level fluctuations in 19 widely spaced wells in the three pumping districts.

In most sections of this country where well irrigation is carried on, the pumps are idle part of the year, usually in winter, and the most de-

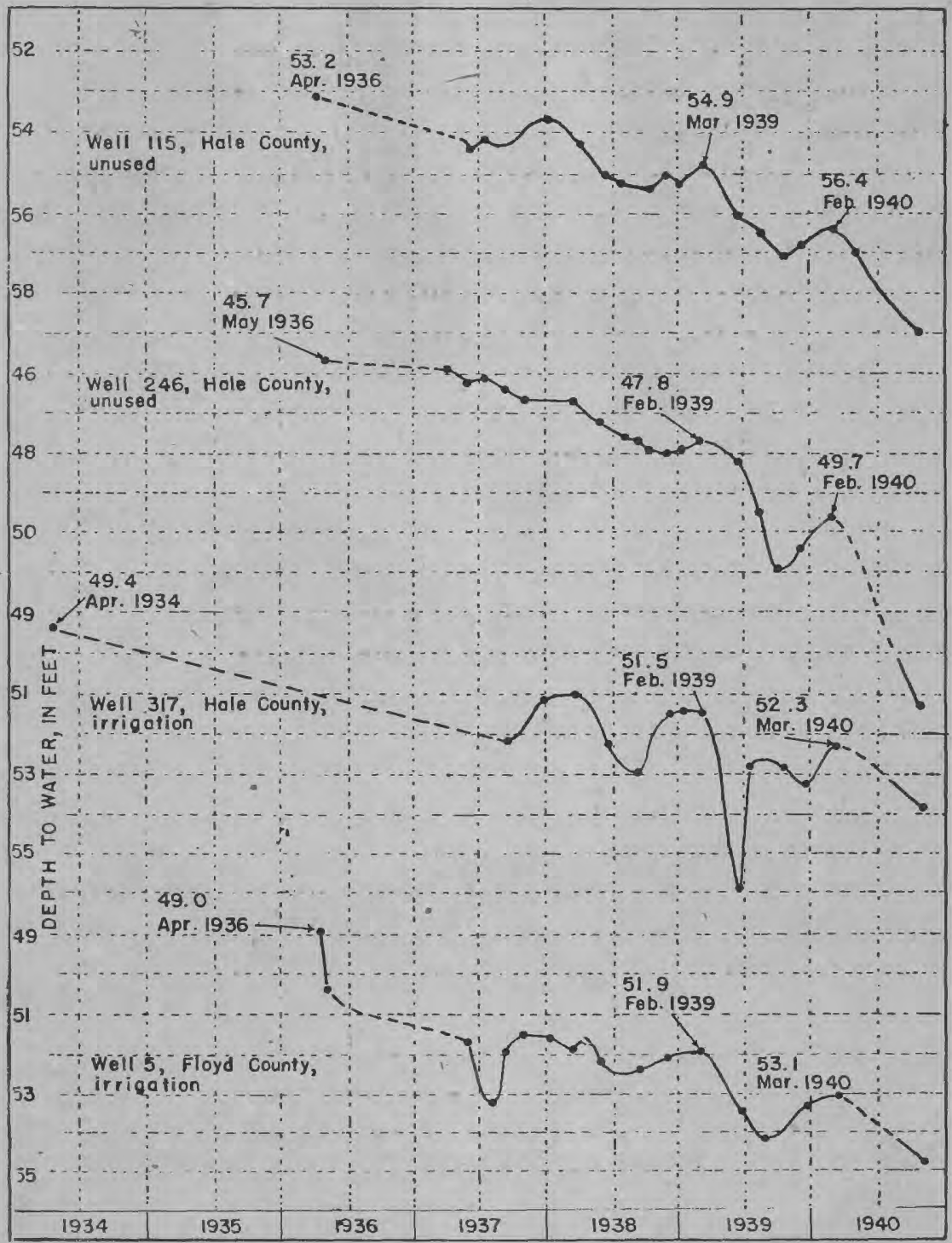

- Measurements recorded in tobles of water-level fluctuations.

Froure 30.-Depth to water in wells in Plainview district, Hale and Floyd Counties, Tex. (areas of moderate pumping)

pendable information regarding the stage of the underground reservoirs is obtained by comparing the water-level measurements made in successive years during the later part of the idle season. In the High Plains of Texas irrigation is practiced during all four seasons and in 
some years the pumps are operated practically every month in the year. Cotton, feed crops, and vegetables are irrigated during the spring, summer, and early fall, and winter wheat during the fall, winter, and

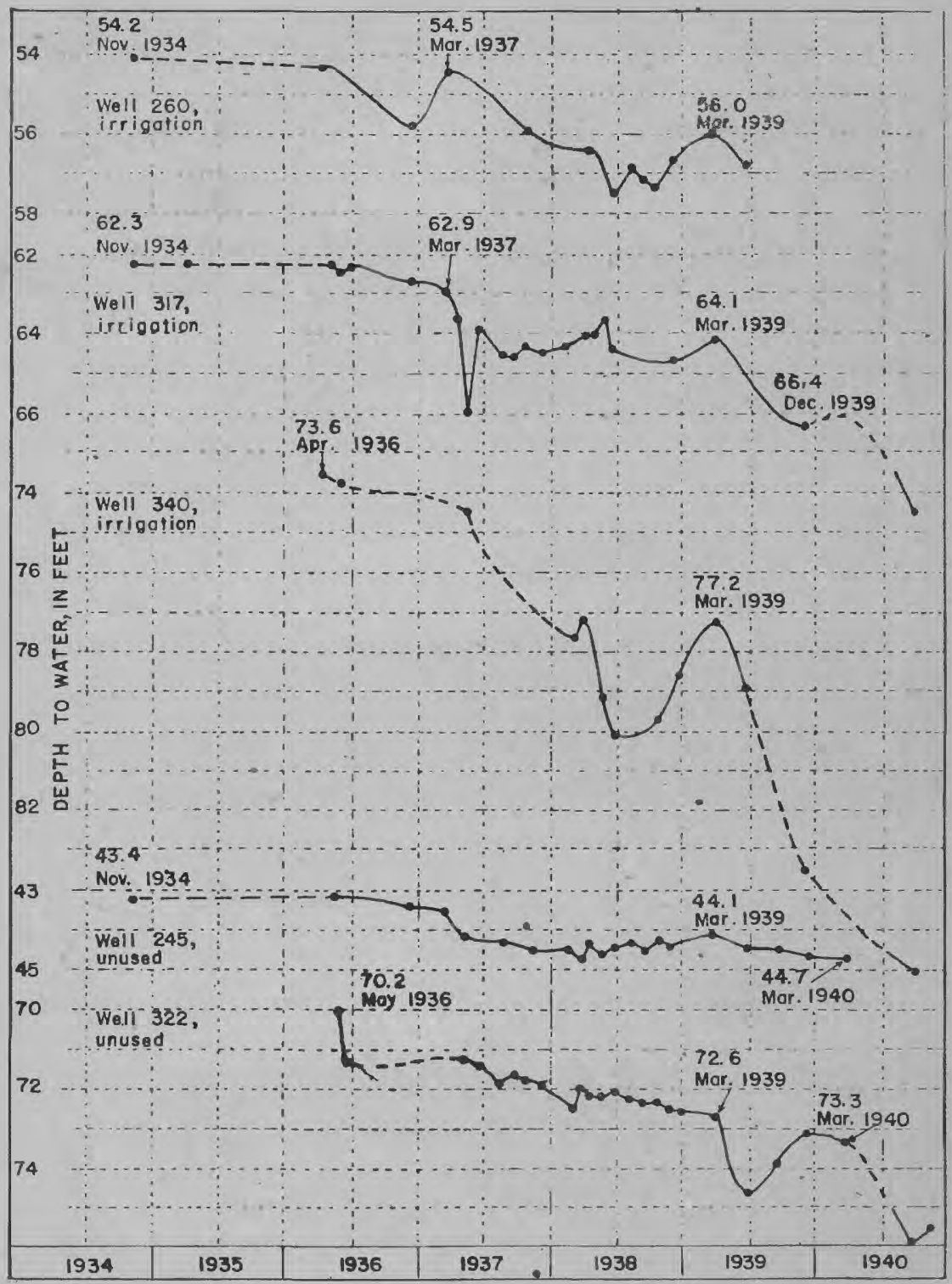

- Meosurements recorded in tables of water-level fluctuations.

Frevre 31.-Depth to water in wells in Plainview district, Floyd County, Tex. (areas of heavy pumping).

spring; the amount of winter irrigation, however, varies greatly with the rainfall from year to year. Taking the area as a whole, winter is the slack season, and a comparison of measurements made late in winter or 
early in spring in successive years is most informative, although in interpreting the measurements allowance must be made for yearly variations in the amount of winter irrigation. In the discussion that

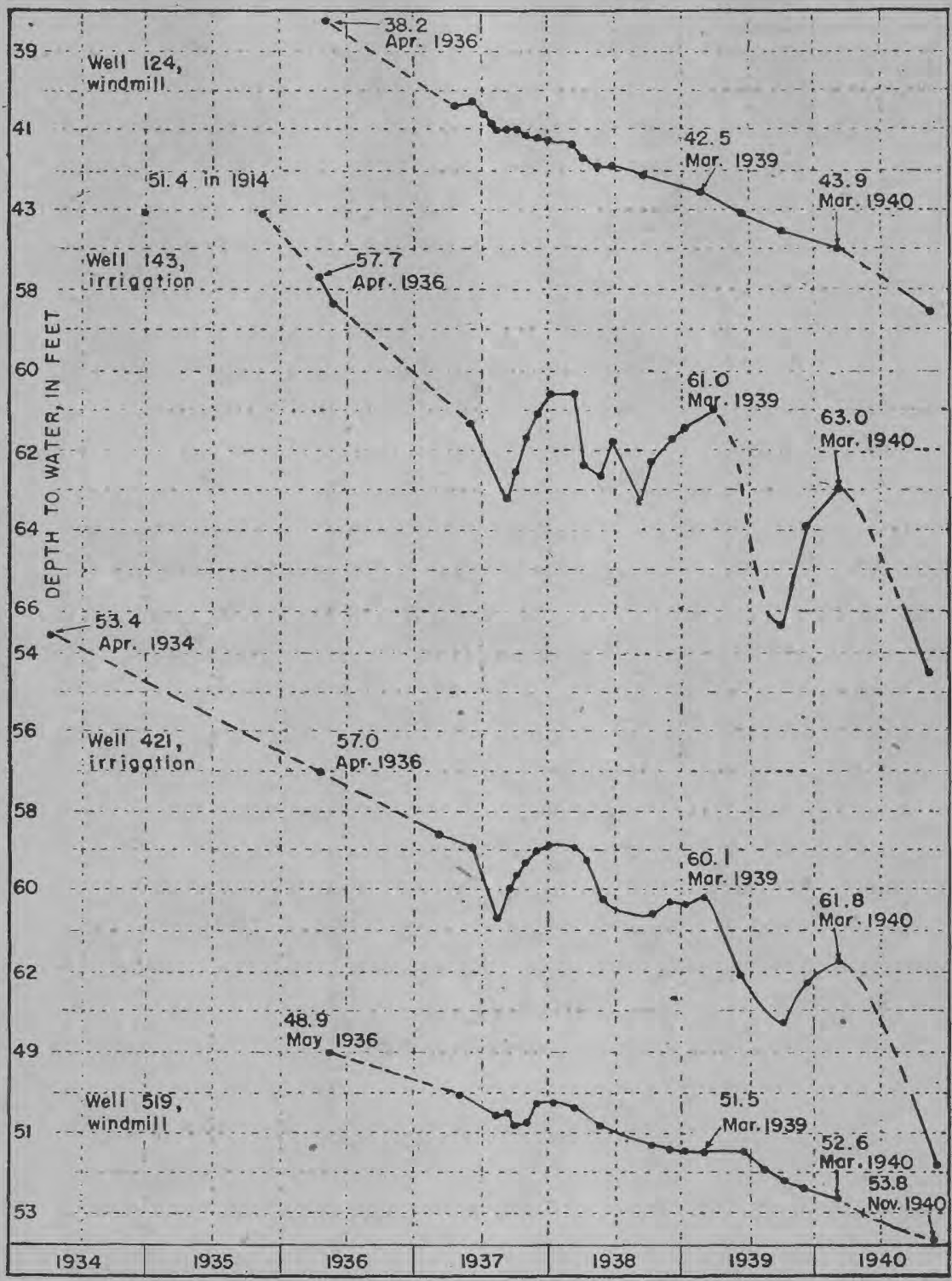

- Meosurements recorded in tables of water-level fluctuations.

Figurn 32,-Depth to water in wells in Hereford district, Deaf Smith County, Tex.

follows, particular copsideration is given to the January to March measurements. 


\section{Plainview District}

About 125 of the observation wells are within a radius of 15 miles from Plainview. (See pl. 19.) For a comparison of water-level fluctuations,

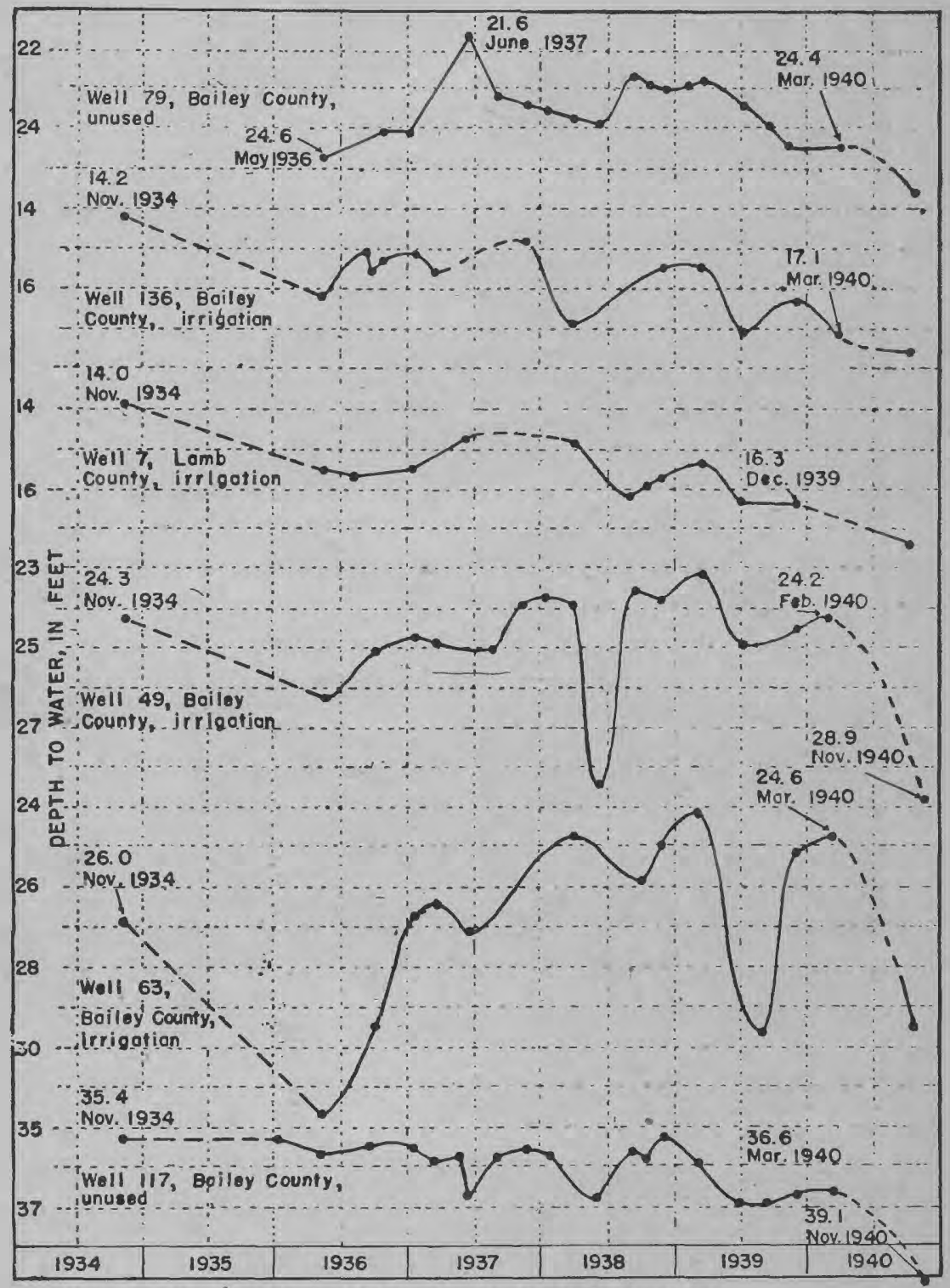

Measurements recorded in tobles of water-level fluctuotians

Fradre 33.-Depth to water in wells in Muleshoe district, Bailey and Lamb Countles, Tex.

with relation to pumpage, the district has been divided into three areas, north and northeast, east and southeast, and south and west, of Plainview. 
North and northeast of Plainview.-Forty-four of the observation wells are in the territory north and northeast of Plainview in northern Hale, southern Swisher, and northwestern Floyd Counties. Detailed records of measurements in 39 of the wells are given on pages 407-408. The area is rather heavily pumped, part of the development being 20 to 25 years old and part comparatively recent. Of the observation wells 16 are pumped for irrigation, 5 are pumped with windmills for domestic use or stock, and 23 are unused.

From January-March 1939 to March 1940 there was an average decline of 1.1 feet in the 32 wells for which measurements are available for comparison. From January-March 1938 to March 1940 the same wells had an average decline of 1.8 feet. In 10 wells with records for April 1936 and March 1940, there was an average decline of 2.6 feet. In 5 wells with records for April 1934 and March 1940 there was an average decline of 3.3 feet. In 1 well which had records for the winter of 1914 and for March 1940 there was a decline of 11.4 feet.

East and southeast of Plainview.-Periodic measurements have been made in 47 observation wells, east and southeast of Plainview, in eastern Hale and western Floyd Counties. Detailed records of measurements in 40 of the wells are given on pages 409-410. This is the most heavily pumped area in the Texas High Plains. About 65 of the irrigation wells here were drilled in 1913-17, mostly within an area of 50 square miles centering around Aiken in western Floyd County. Most of these wells were operated only a part of the time until about 1934 . Since 1934 the number of irrigation wells east and southeast from Plainview has increased more than 200 percent.

Of the observation wells 19 are not used, 21 are pumped for irrigation, and 4 are equipped with a windmill. From January-March 1939 to March 1940 there was an average net decline of 1.6 feet in the 34 wells for which comparable measurements are available. From JanuaryMarch 1938 to March 1940 the same wells had an average decline of 2.6 feet. The 7 wells measured during March-April 1937 and in March 1940 showed an average decline of 2.3 feet. The 8 wells measured in April 1936 and in March 1940 had an average decline of 3.5 feet. From April 1934 to March 1940, the 5 wells measured had an average decline of 6.5 feet. From 1914 to March 1940, 10 wells showed an average decline of 9.6 feet. The greatest decline, 14.2 feet, occurred near the center of the old pumped area.

South and west of Plainview.-Forty of the observation wells are south and west of Plainview where the pumping is somewhat lighter than in the other parts of the district, and most of the wells have been put into operation since 1935 . Of the observation wells 23 are not used, 11 are pumped for irrigation, 5 are equipped with windmills, and 1 is equipped with a hand pump. Detailed records of measurements in all these wells are given on pages 411-412. From March 1939 to March 1940 there was an average decline of 0.8 foot in 28 wells for which records are available. Twenty-three wells measured in March 1938 and March 1940 had an average decline of 1.3 feet. Three wells measured in March 1937 and March 1940 had an average decline of 1.2 feet. Four wells measured in April 1934 and March 1940 had an average decline of 1.5 feet. Of 5 wells measured in 1914 and February-March 1940, 4 had an average decline of 0.8 foot and one a rise of 3.8 feet.

Summary.-A summary giving the minimum, maximum, and average decline of water levels in the Plainview district for the different periods is given in the table below. 
Decline of water levels in observation wells in Plainview district, Tex.

\begin{tabular}{|c|c|c|c|c|c|}
\hline \multirow{2}{*}{ Period } & \multirow{2}{*}{$\begin{array}{l}\text { Number } \\
\text { of } \\
\text { wells }\end{array}$} & \multicolumn{3}{|c|}{$\begin{array}{l}\text { Net decline of water levels } \\
\text { (feet) }\end{array}$} & \multirow{2}{*}{ Remarks } \\
\hline & & Minimum & Maximum & Average & \\
\hline $\begin{array}{l}\text { Noth and northeast of Plainview: } \\
1939-40 \\
1938-40 \\
1936-40 \\
1934-40 \\
1914-40 \\
\text { East and southeast of Plainview: } \\
1939-40 \\
1938-40 \\
1937-40 \\
1936-40 \\
1934-40 \\
1914-40 \\
\text { South and west of Plainview: } \\
1939-40 \\
1938-40 \\
1937-40 \\
1934-40 \\
1914-40\end{array}$ & $\begin{array}{r}32 \\
32 \\
10 \\
5 \\
1 \\
34 \\
34 \\
7 \\
8 \\
5 \\
10 \\
28 \\
23 \\
3 \\
4 \\
5\end{array}$ & $\begin{array}{r}0.2 \\
.6 \\
1.4 \\
2.0 \\
.4 \\
.6 \\
1.6 \\
1.6 \\
4.7 \\
5.7 \\
.1 \\
.3 \\
.9 \\
1.4 \\
.2\end{array}$ & \begin{tabular}{r|}
2.5 \\
3.7 \\
4.2 \\
5.4 \\
1.5 \\
2.7 \\
4.6 \\
3.3 \\
5.7 \\
8.3 \\
14.2 \\
1.5 \\
2.9 \\
1.5 \\
1.6 \\
1.5
\end{tabular} & $\begin{array}{r}1.1 \\
1.8 \\
2.6 \\
3.3 \\
11.4 \\
1.6 \\
2.0 \\
2.3 \\
3.5 \\
6.5 \\
9.6 \\
.8 \\
1.3 \\
1.2 \\
1.5 \\
.8\end{array}$ & $\begin{array}{l}\text { Rise of } 3.8 \text { feet in } \\
\text { one well. }\end{array}$ \\
\hline
\end{tabular}

\section{Hereford District}

About 70 of the observation wells are in this district, most of them within 12 miles of Hereford. (See pl. 20.) The rainfall there during the early part of 1937 was exceptionally small, and apparently more water was pumped than during corresponding periods in 1938 and 1939. This was reflected in the water-level measurements, and a comparison of the spring measurements in 1937 with those in 1938 and 1940 therefore tend to give figures on the net decline in water levels that are less than the true net decline.

North and northeast of Hereford.-Most of the older irrigation wells and many of those that were put down from 1936 to 1939 are in the area north and northeast of Hereford, which is now the most heavily pumped part of the Hereford district.

Of the 31 observation wells in the area, 18 are pumped for irrigation, 11 are unused, and 2 are equipped with a windmill. Of these wells 21 are located in or bordering the area of most intensive pumping and 10 are where pumping is light to moderate. Detailed records of measurements are given on pages 413-414. From March 1939 to March 1940 there was an average decline of 1.4 feet in the 24 wells for which measurements are available. From January-March 1938 to March 1940 these wells showed an average loss of 1.3 feet and 1 well a net rise of 1.7 feet. Water levels recorded in April to June 1936 and in March 1940 show an average decline of 2.3 feet in 12 wells and a rise of 0.1 foot in 1 well. Of 2 wells measured in November 1934 and in March 1940 one had a decline of 2.5 feet and the other a decline of 1.3 feet. One well (No. 261, Deaf Smith County) about 3 miles north of Hereford had a decline of 5.8 feet from 1914 to March 1940.

South and southeast of Hereford.-The area south and southeast of Hereford is heavily pumped but the draft is not quite so great as it is in the area to the north and northeast. Of the 20 observation wells in this part of the district 4 are unused. Detailed records of measurements are given on page 415. From March 1939 to March 1940 there was an average decline of 1.2 feet in the 16 wells for which measurements are available. From January-March 1938 to March 1940, the same wells 
showed an average decline of 1.1 feet. One well measured in March 1937 and in March 1940 had a decline of 2.8 feet. A comparison of the highest water levels recorded in April to June 1936 with measurements made in March 1940 shows an average decline of 2.5 feet in 7 wells and an average rise of 0.5 foot in 3 wells.

West and southwest of Hereford.-Most of the irrigation wells west and southwest of Hereford have been put in during the last 3 or 4 years, and in general they are rather widely spaced. Of the 10 observation wells in this area 4 are unused, 3 are pumped for irrigation, and 3 are equipped with windmills. For detailed records of measurements see page 416 . From March 1939 to March 1940 there was an average decline of 0.8 foot in 6 wells for which measurements are available. From March 1938 to March 1940 the decline in these wells was practically the same as it was from 1939 to 1940 . One well (No. 283, Deaf Smith County) showed a decline of 3.2 feet between May 1936 and March 1940.

Summary.-A summary giving the maximum, minimum, and average decline of water levels in the Hereford district for the various periods is given in the table below.

Decline of water levels in observation wells in Hereford district, Tex.

\begin{tabular}{|c|c|c|c|c|c|}
\hline \multirow{2}{*}{ Period } & \multirow{2}{*}{$\begin{array}{l}\text { Number } \\
\text { of } \\
\text { wells }\end{array}$} & \multicolumn{3}{|c|}{$\begin{array}{l}\text { New decline of water levels } \\
\text { (feet) }\end{array}$} & \multirow{2}{*}{ Remarks } \\
\hline & & Minimum & Maximum & Average & \\
\hline $\begin{array}{l}\text { North and northwest of Hereford: } \\
\quad 1939-40 \\
1938-40\end{array}$ & $\begin{array}{l}24 \\
24\end{array}$ & $\begin{array}{l}0.1 \\
0\end{array}$ & $\begin{array}{l}2.7 \\
2.2\end{array}$ & $\begin{array}{l}1.4 \\
1.3\end{array}$ & Rise of 1.7 feet in \\
\hline $1936-40 \ldots$ & 13 & .2 & 6.7 & 2.3 & $\begin{array}{l}\text { Rise of } 0.01 \text { foot in } \\
\text { one well. }\end{array}$ \\
\hline $1934-40$ & $\stackrel{2}{1}$ & 1.3 & 2.5 & $\begin{array}{l}1.9 \\
5.8\end{array}$ & \\
\hline $\begin{array}{l}\text { South and southeast of Hereford: } \\
1939-40 \text {. } \\
1938-40 \\
1937-40\end{array}$ & $\begin{array}{c}16 \\
16 \\
1\end{array}$ & .2 & $\begin{array}{l}3.1 \\
2.8\end{array}$ & $\begin{array}{r}1.2 \\
-\quad 1.1 \\
2.8\end{array}$ & \\
\hline $1936-40$ & 10 & .5 & 4.0 & 2.5 & $\begin{array}{l}\text { Average rise of } 0.5 \\
\text { foot in } 3 \text { wells. }\end{array}$ \\
\hline $\begin{array}{l}\text { South and west of Hereford: } \\
\quad 1939-40 \\
1938-40 \\
1936-40\end{array}$ & $\begin{array}{l}6 \\
6 \\
1\end{array}$ & $\begin{array}{l}0 \\
0\end{array}$ & $\begin{array}{l}2.0 \\
1.1\end{array}$ & $\begin{array}{r}.8 \\
.6 \\
3.2\end{array}$ & \\
\hline
\end{tabular}

\section{Muleshoe District}

- Measurements have been made in about 40 observation wells in the Muleshoe district (see pl. 21) at intervals ranging from 1 to 4 months. Of these wells 33 are pumped for irrigation and 7 are unused.

East of Muleshoe.- Twenty-two of the observation wells are in the pumped area east of Muleshoe which comprises about 40 square miles. Detailed records of measurements are given on page 417. From March 1939 to March 1940 there was an average decline of 0.7 foot in 17 wells for which comparable measurements are available. The 16 wells measured during January-March 1938 and in March 1940 showed an average decline of 0.5 foot. From January-May 1937 to March 1940 the 16 wells measured had a decline of 0.4 foot. From November 1934 to December 1939, 6 wells showed an average decline of 2.4 feet. From 1914 to March 1940, 10 wells had an average decline of 2.8 feet.

West of Muleshoe.-The pumped area west of Muleshoe comprises about 25 square miles. Of the 17 observation wells in this area 13 
are pumped for irrigation and 3 are unused. From March 1939 to March 1940 the 16 wells had an average decline of 0.8 foot and from JanuaryMarch 1938 to March 1940, 14 of them had an average decline of only 0.2 foot. Seven wells measured during January-May 1937 and in March 1940 showed an average rise of 1.1 feet. Of 2 wells measured in November 1934 and in December 1939, one had a decline of 0.2 foot and the other a rise of 1.8 feet.

\section{LUBBoCK-LiTTLEFIELD DisTRICT}

Observations of water levels are being made at intervals ranging from 1 to 4 months in about 30 wells in the Lubbock-Littlefield district, comprising northern Lubbock, northeastern Hockley, and southeastern Lamb Counties. Of 27 wells measured during the winter of 1938-39 and during corresponding months in 1939-40, 22 had declines ranging from 0.2 foot to 2.2 feet and averaging 0.7 foot, while 5 wells had an average rise of 0.46 foot. Four of the five wells displaying a rise are near intermittent ponds or the valley of Yellowhouse Draw. The 29 wells measured in December 1937 or January 1938 and in corresponding months in 1939-40 had an average decline of 0.5 foot.

\section{Texline District}

In the Texline district in Dallam County, water-level measurements are being made in about 25 observation wells, of which 18 were measured monthly in 1939. Of 18 wells measured in March 1939 and in March 1940, 12 had an average decline of 0.5 foot and 6 an average rise of 0.1 foot. One well had a decline of 1.3 feet from November 1934 to March 1940.

\section{EFFECT OF PUMPING ON GROUND-WATER SUPPLY}

There has been a general decline in the water table in the principal pumping districts of the High Plains during the past few years. The decline has been spread over large areas and the total volume of formerly saturated material that has been unwatered by the decline is large. The water that has drained out as the water table declined has moved downward to replace the pumped water and represents a loss from the volume formerly in storage. The interstices in sand and gravel are comparatively large, and consequently the effect of molecular attraction in them tending to resist the pull of gravity is comparatively slight. Therefore a large part of the water which they contain in a saturated condition drains out as the water table declines. In other words, the specific yield is high. The pore spaces in silt and clay loams are very small, and the effect of molecular attraction in them is correspondingly great. These materials therefore retain a much higher proportion of water as the water table declines than is retained by sand and gravel. The process of drainage in fine materials continues for a long time, although at a greatly reduced rate. If on the average the saturated materials in the pumping districts of the High Plains have a specific yield of 15, that is, if they yield a volume of water equivalent to 15 percent of their own volume as they are unwatered, a total of 96 acre-feet is removed from storage in each square mile for each foot of decline.

In an area of about 300 square miles southeast of Plainview, the water table apparently had an average decline of about 1.5 feet from March 1938 to March 1940. If a 1 -foot decline in the water level removed 96 
acre-feet from storage for each square mile, a decline of 1.5 feet over 300 square miles removed about 43,000 acre-feet. The records show that in the 2-year period a total of about 80,000 acre-feet of water was pumped in this part of the Plainview district.

Approximately 90 percent of the wells in the entire Plainview district are within an area of about 700 square miles. In this area the water table apparently had an average decline of about 1.2 feet from March 1938 to March 1940. Making the same assumption as above regarding the specific yield, this would indicate that approximately 84,000 acrefeet of water was removed from storage in the area during the 2 years. The pumpage in the area during the period is estimated at about 170,000 acre-feet.

Approximately 80 percent of the wells in the Hereford district are in an area of about 270 square miles. In this area the water table apparently had an average decline of about one foot from March 1938 to March 1940. On the same basis as above this decline would indicate that about 26,000 acre-feet were removed from storage. The pumpage in the 270 square miles during the 2 years is estimated at about 46,000 acre-feet. Quantities of water were also withdrawn from storage in areas surrounding those described above as water moved toward the depressions in the water table produced by the pumping. The observation wells in the adjoining areas are few and widely spaced and the amount of the withdrawals can not be computed.

Further investigation will be required to correlate the above estimates precisely with the results obtained as to natural discharge and recharge. The records are conclusive, however, in showing that the pumped water is in large part taken from storage.

In the High Plains before any water was pumped from wells the yearly discharge of ground water by natural process was doubtless about equal to the average amount added yearly from the rain and snow falling on the region. The pumping has represented an additional amount of water taken from the underground reservoir without any increase in the amount of replenishment. Hence the development of the ground-water resources of the region will necessarily cause lowering of the water level except as natural discharge is decreased.

\section{CONCLUSIONS}

A very large quantity of water, which has accumulated over a long period of time, is stored in the natural underground reservoir formed by the beds of sand and gravel that lie below the. High Plains of Texas. A small part of this water is discharged each year by the flow of springs or by evaporation and the growth of plants in the localities where the water table is near the surface. This natural discharge is approximately balanced through a long term of years by water derived from that part of the rainfall upon the area which penetrates to the water table. The average annual replenishment is only a small part of the average annual rainfall.

During the past 30 years water has been pumped from wells in this region in large quantities, chiefly for irrigation. The annual pumpage increased greatly from 1934 to 1939 . In 1937 it amounted to about 130,000 acre-feet; in 1938 to about 145,000 acre-feet; and in 1939 to about 165,000 acre-feet.

There has been a general and persistent decline of the water table in the pumping districts during the past few years. A large part of the 
water pumped from wells in this region has been derived by reduction in underground storage.

Questions in the minds of many owners of irrigation wells in the High Plains are these: What are the limits of safe pumping in my neighborhood? How much water should be pumped and how closely should the wells be spaced? The investigation shows that these are largely questions of economics. With increased pumping the rate of decline of the water table and the pumping lift will increase. Moreover, as the uppermost sands and gravels are unwatered, the wells that draw from them probably will decline in yield. With their water supply, the farmers of the High Plains are in a position similar to that of a man who has a large capital but who uses a part of his capital each year.

Obviously, the problem of the conservation of the stored ground water for future as well as present beneficial use deserves serious consideration.

\section{RECORDS OF WATER LEVEL MEASUREMENTS}

This report is devoted mostly to the results obtained from the investigation prior to April 1, 1940. However, the results of measurements, made to the middle of November 1940, of water levels in wells in the more heavily pumped areas have been included in the tables of waterlevel measurements on the pages that follow. ${ }^{15}$

16 For brief summary of conditions in later years, see Addendum, p, 419. 


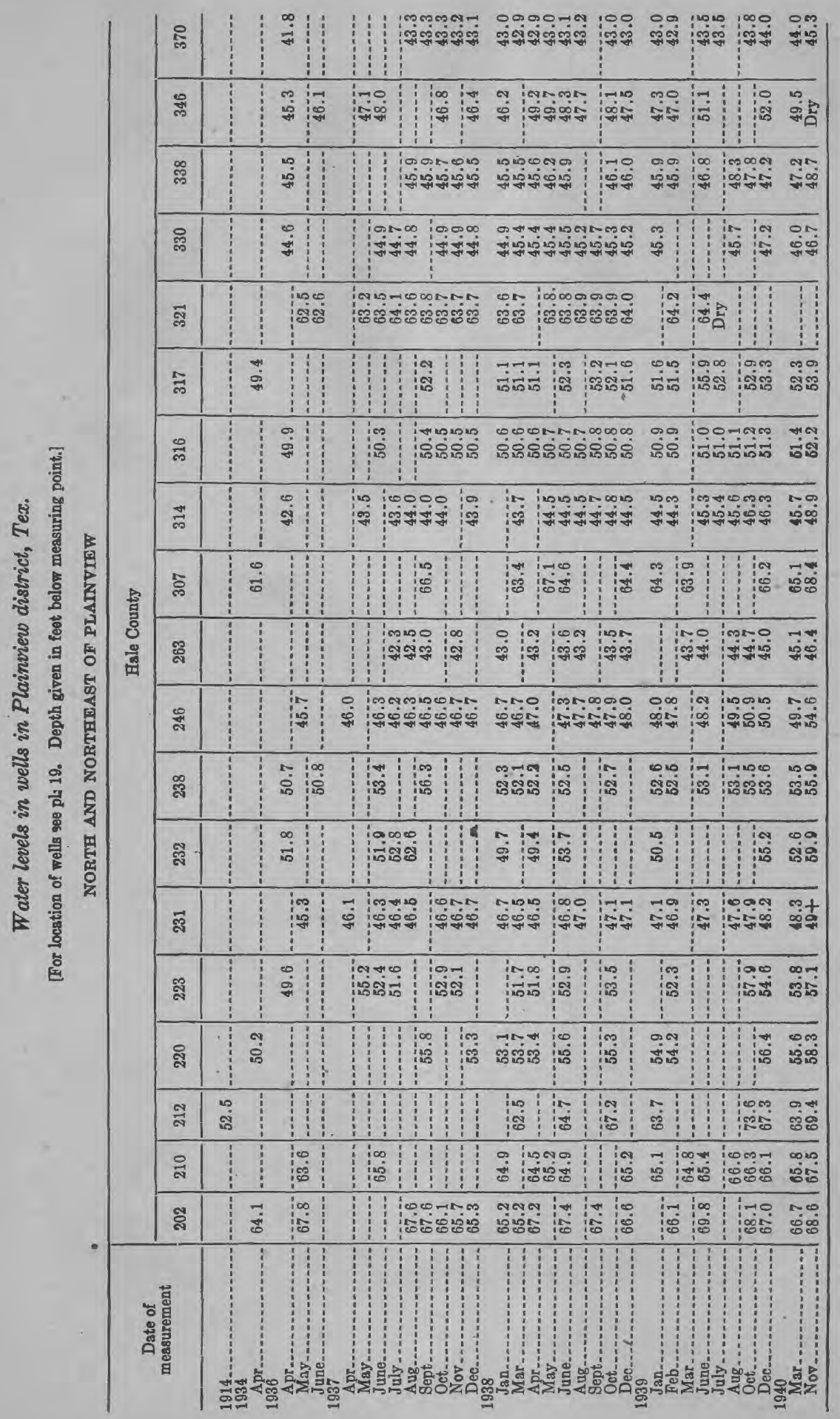




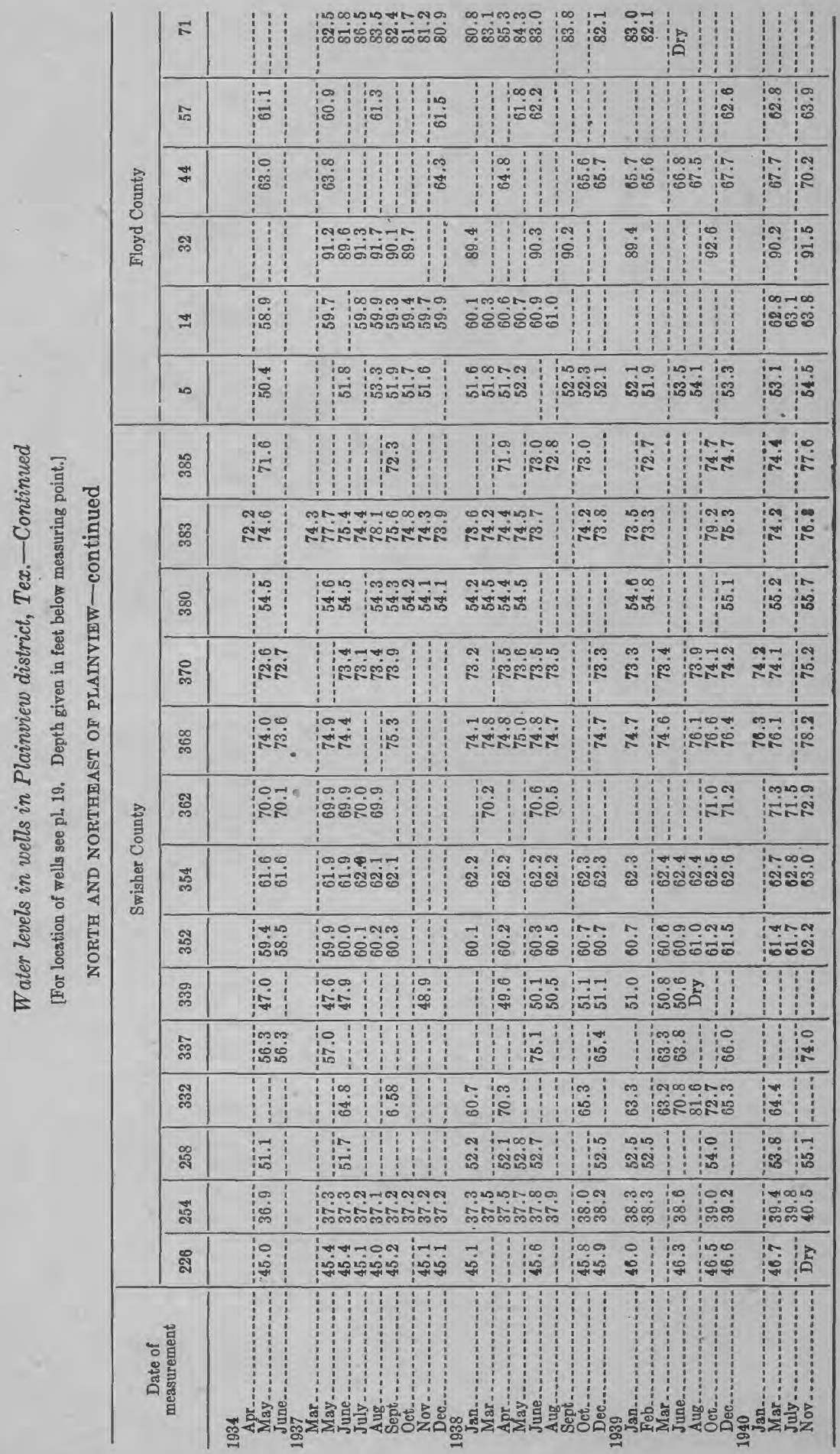




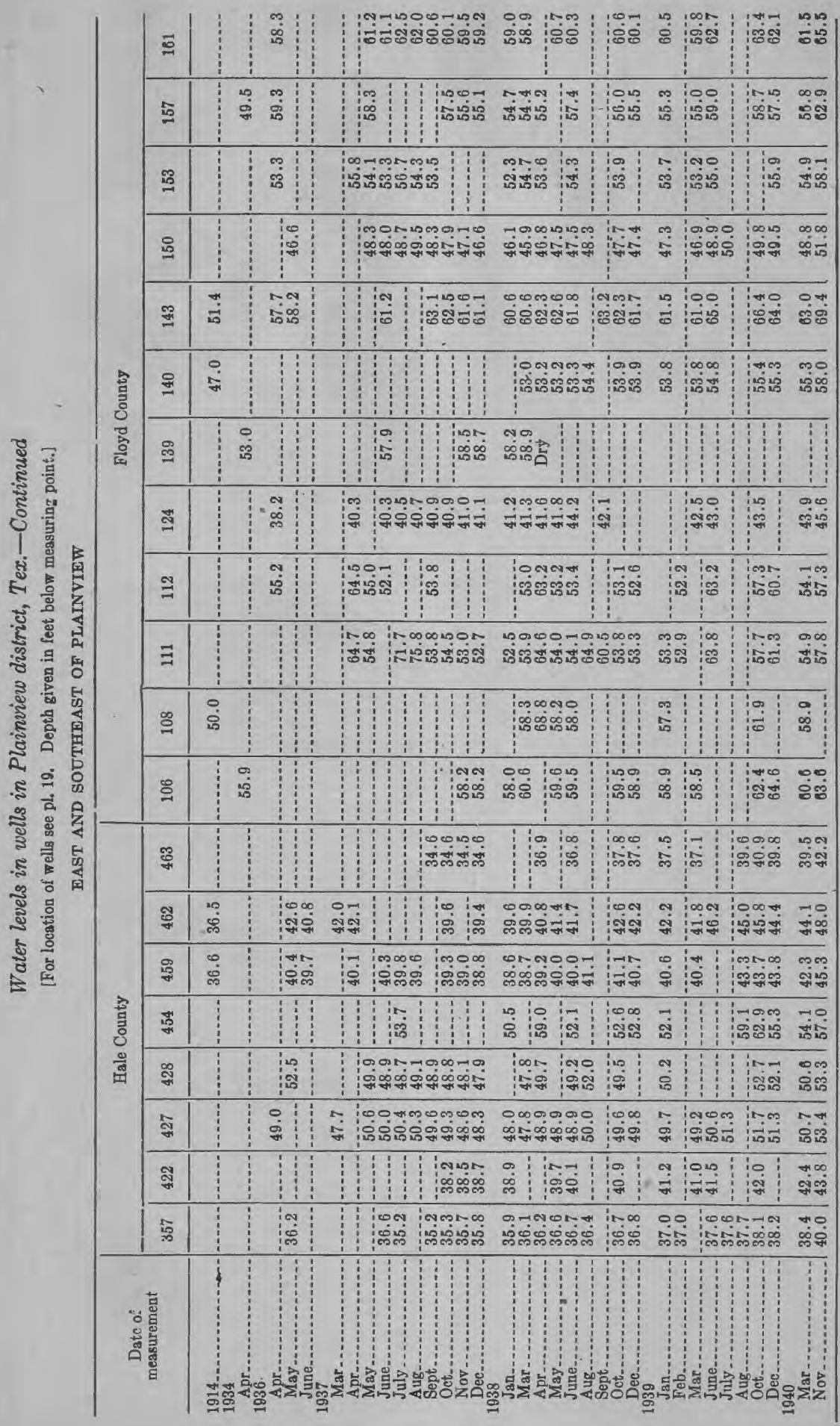




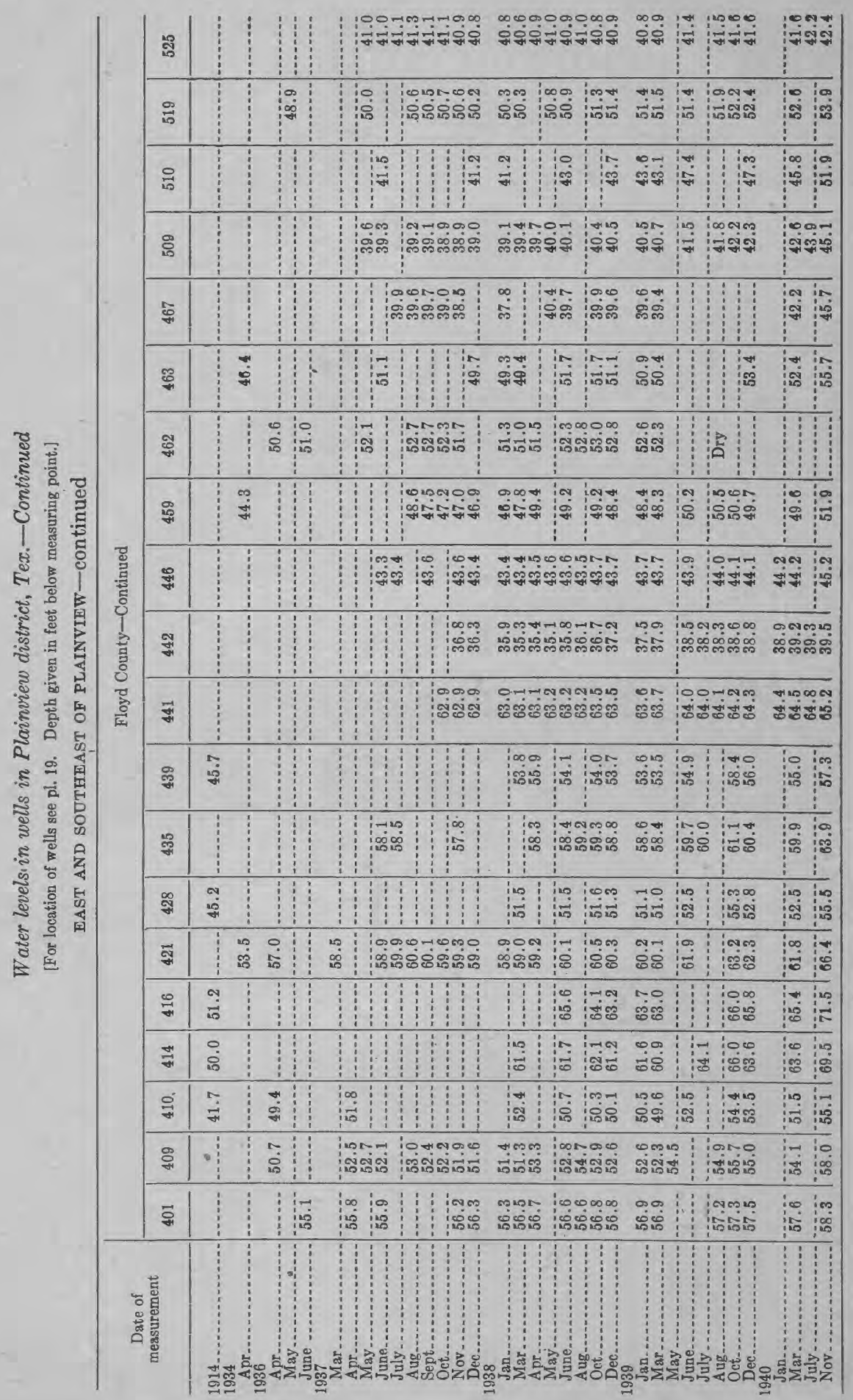




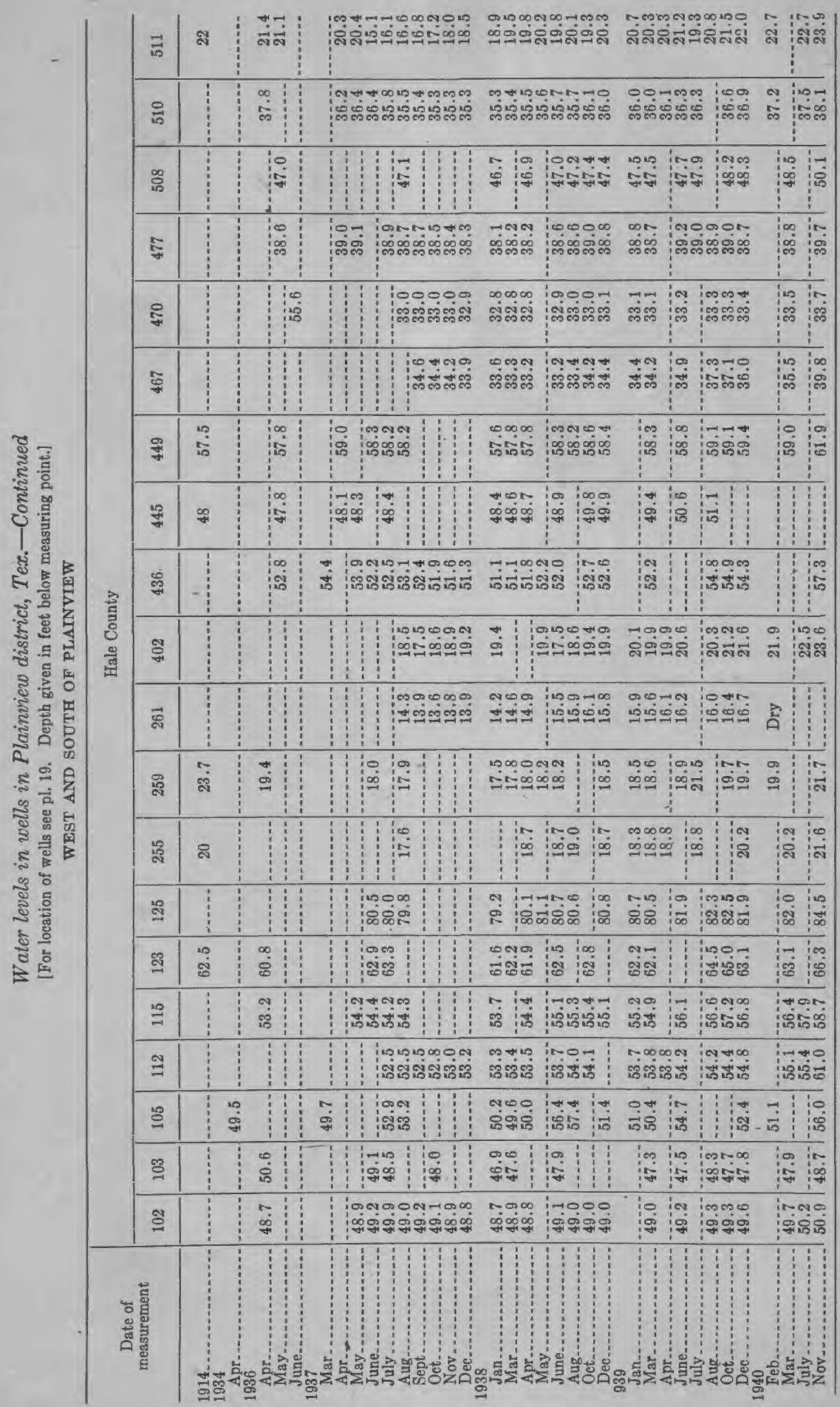




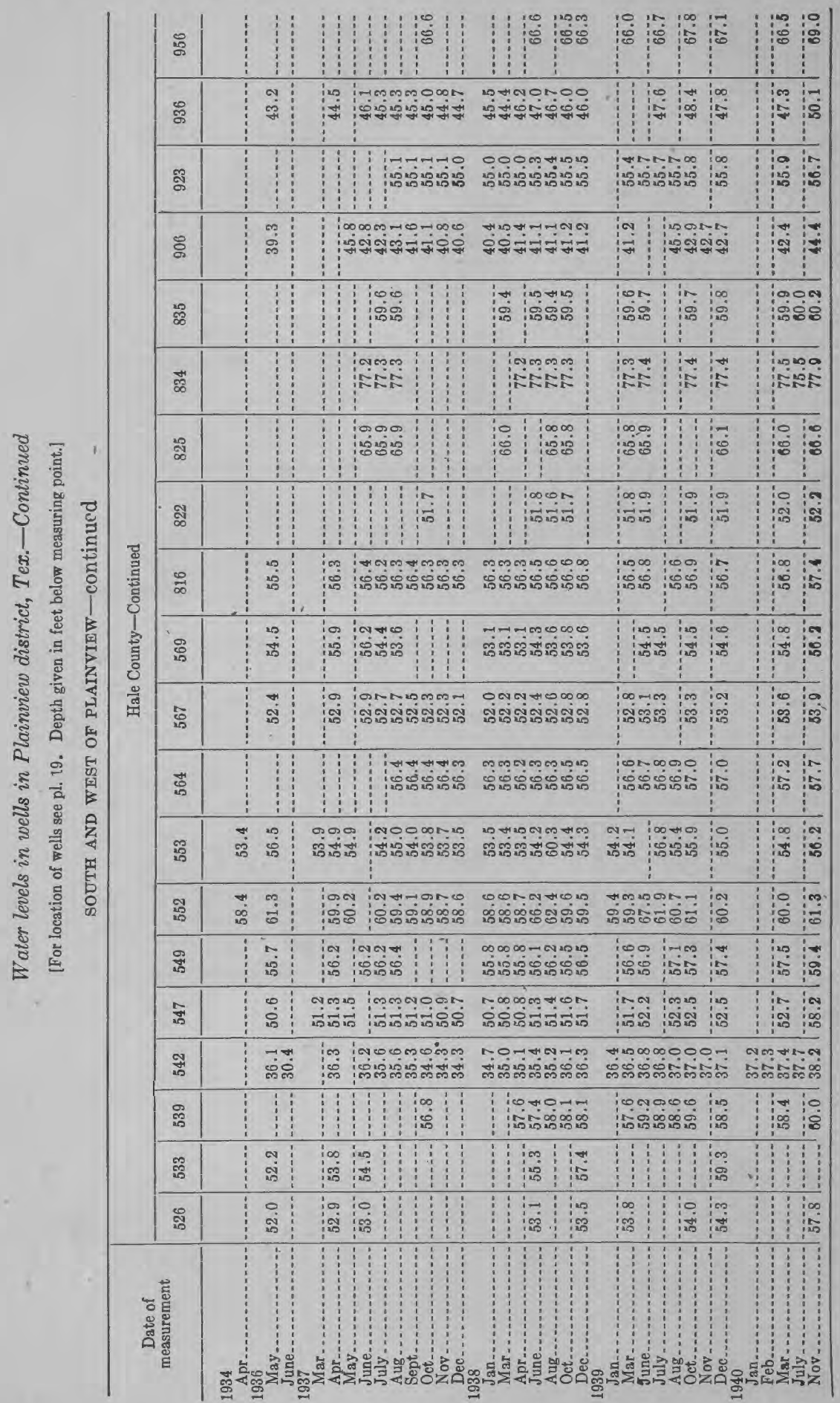




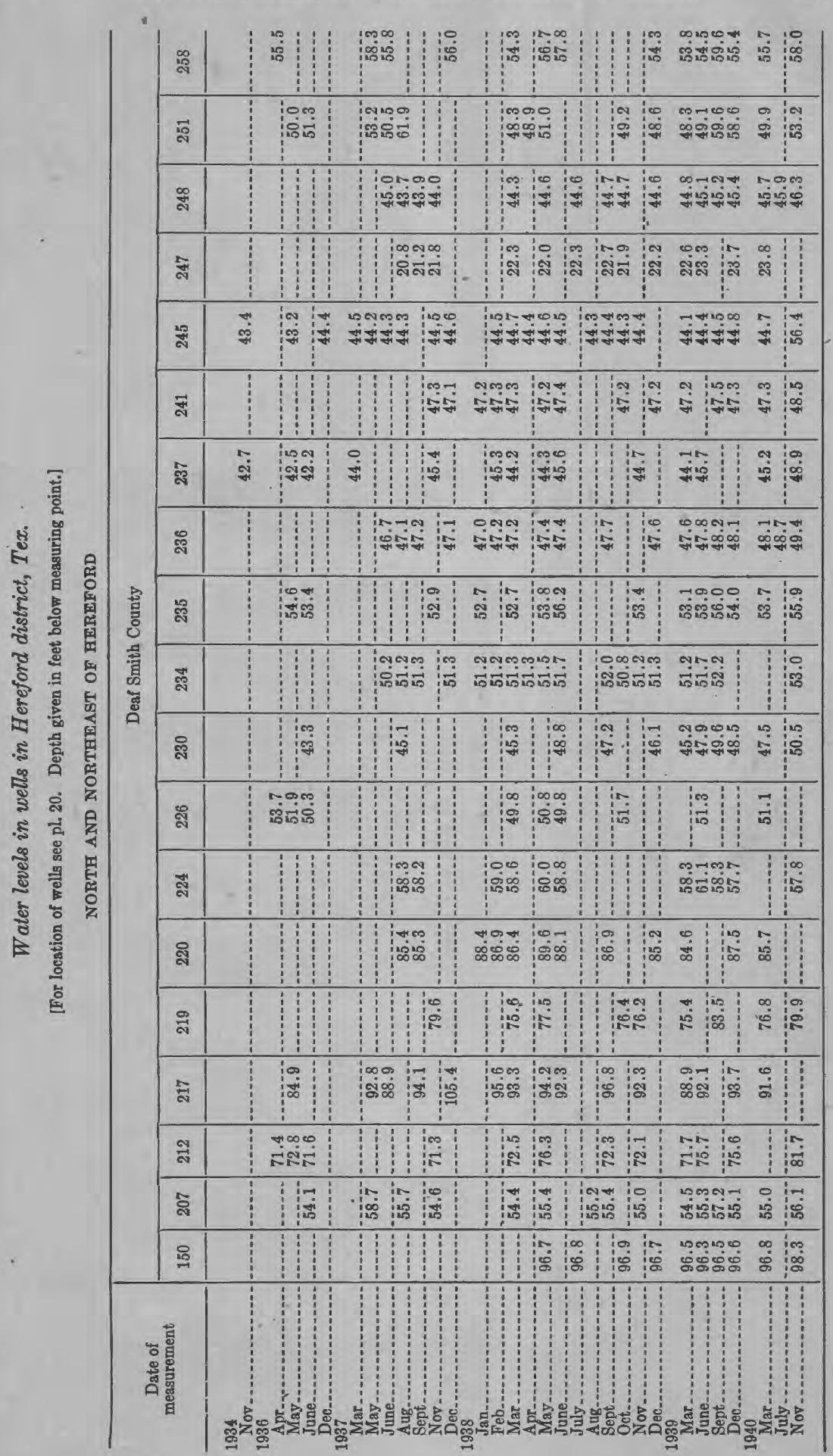




\section{CONTRIBUTIONS TO HYDROLOGY OF UNITED STATES, 1941-43}

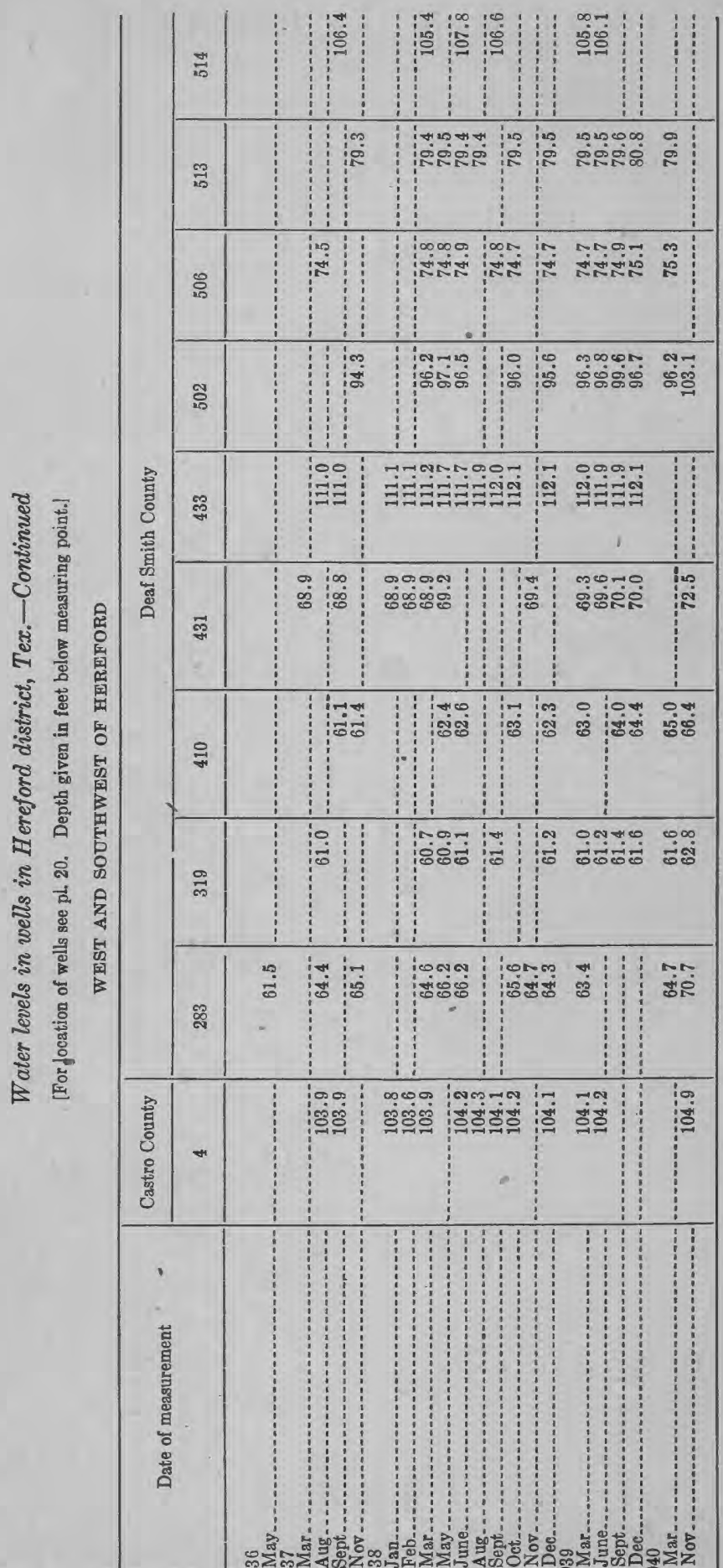




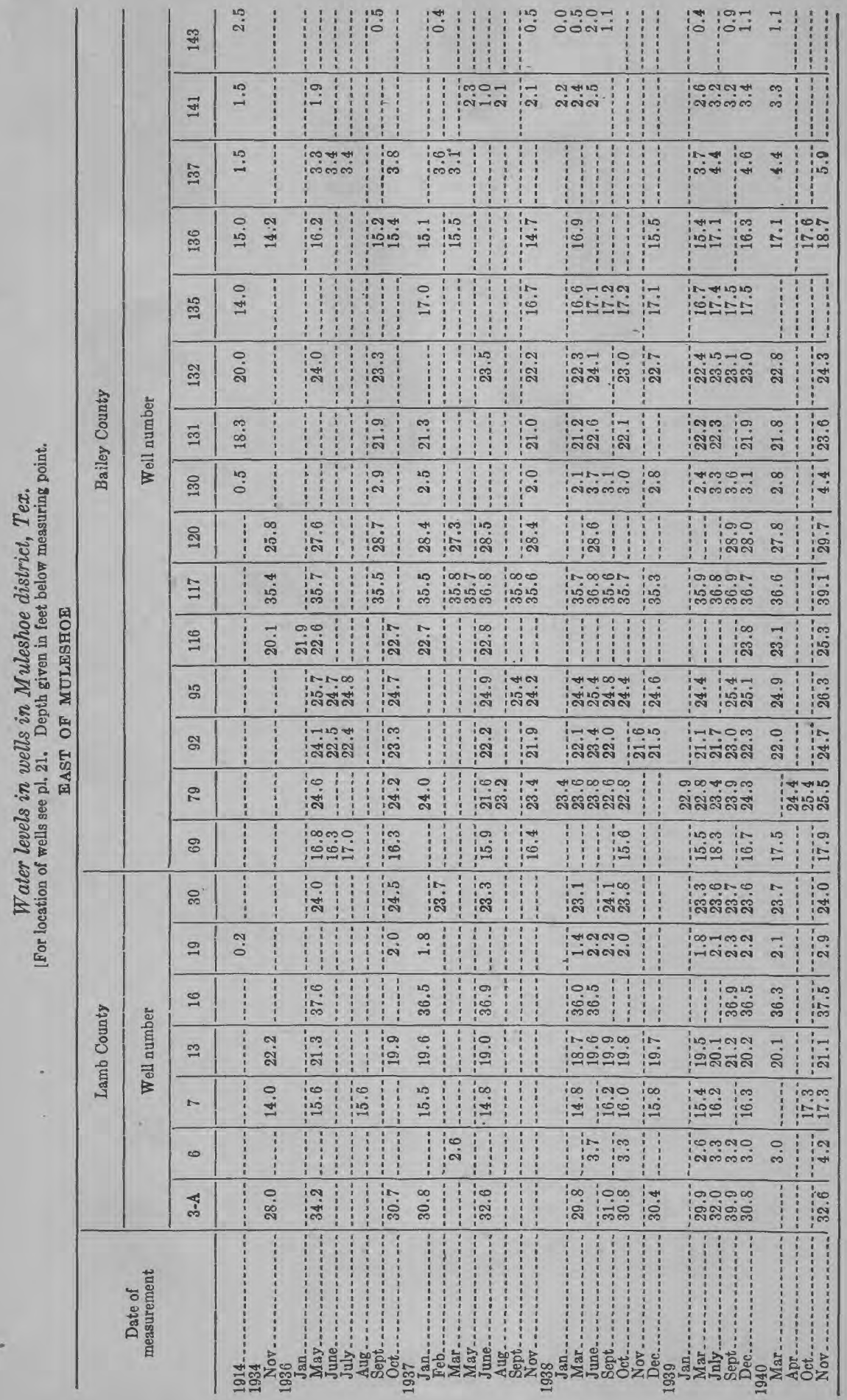


418 CONTRIBUTIONS TO HYDROLOGY OF UNITED STATES, 1941-43

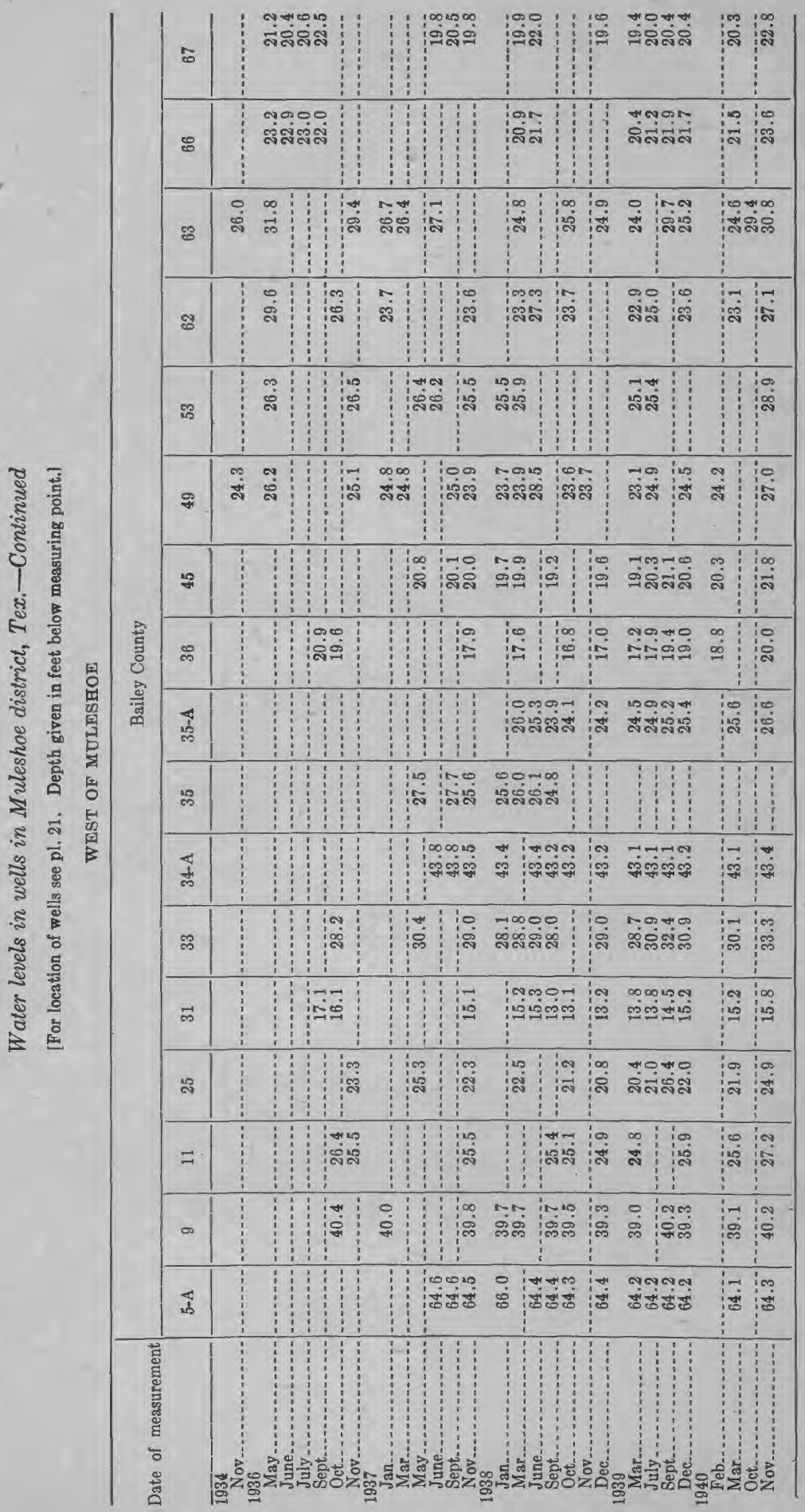




\title{
ADDENDUM
}

\author{
May 1945
}

Since the foregoing report was written, inventories of irrigation wells and rough estimates of the total pumpage have been made each year, and periodic measurements of water levels in observation wells have been continued. The results of these studies to February 1944 are given in two mimeographed reports, one of which was released in April 1943 , and the other in May $1944 .^{16}$

By the late winter of 1944-45 about 3,500 wells had been completed, the area under irrigation had reached about 450,000 acres, and the total area within the exterior boundaries of the principal irrigation districts had reached about $3,000,000$ acres; hence about 15 percent of the total area within these boundaries was irrigated, and there was on the average one well to about 850 acres. In the more heavily pumped localities the wells were much more closely spaced, the average being one well to 280 acres in one area of 50 square miles, and one well to 300 acres in another area of 50 square miles. Briefly summarized the number of wells in operation from 1940 to 1944 was as follows: 1940, 2,180; $1941,2,560 ; 1942,2,680 ; 1943,2,950$; and $1944,3,500$.

From 1937 to 1941, a period of subnormal precipitation, the increase in irrigation was accompanied by a persistent decline of the water table, as shown by records of water-level measurements in about 300 observation wells.

During 1941 the precipitation was very heavy, the heaviest on record in parts of the region. Consequently, the water requirements for irrigation were small, recharge to the ground-water reservoirs was several times that in average years, and the observation wells in all the pumping districts showed a pronounced rise in water levels.

During 1942 the precipitation was again above average, pumping was again light, and the water levels in most of the wells either remained nearly stationary or rose slightly.

During 1943 the precipitation was materially below the average, the pumping was greater than ever before, and most of the observation wells showed a decline in water levels.

During 1944 the precipitation was slightly above average and less water was used per acre than was used in 1943 but the total pumpage was about the same as it was in 1943 owing to the added requirements of new wells; and most of the observation wells showed a decline in water levels.

From the spring of 1938 to February 1945 the records of water level measurements in 192 observation wells in the irrigation areas showed net changes as follows: Plainview district, decline 4.6 feet; Hereford district, decline 3.0 feet; Muleshoe district, rise 3.3 feet; LubbockLittlefield district, rise 2.5 feet.

16 Alexander, W. H., Jr., Progress report on ground water in the High Plains in Texas, 34 pp. il., Texas State Board of Water Engineers Apr. 1943. Broadhurst, W. L, and Alexander, W. H., Jr., Progress report on ground water in the High Plains in Texas, 19 pp. il., Texas State Board of Water Engineers, May 1944. 


\section{N DEX}

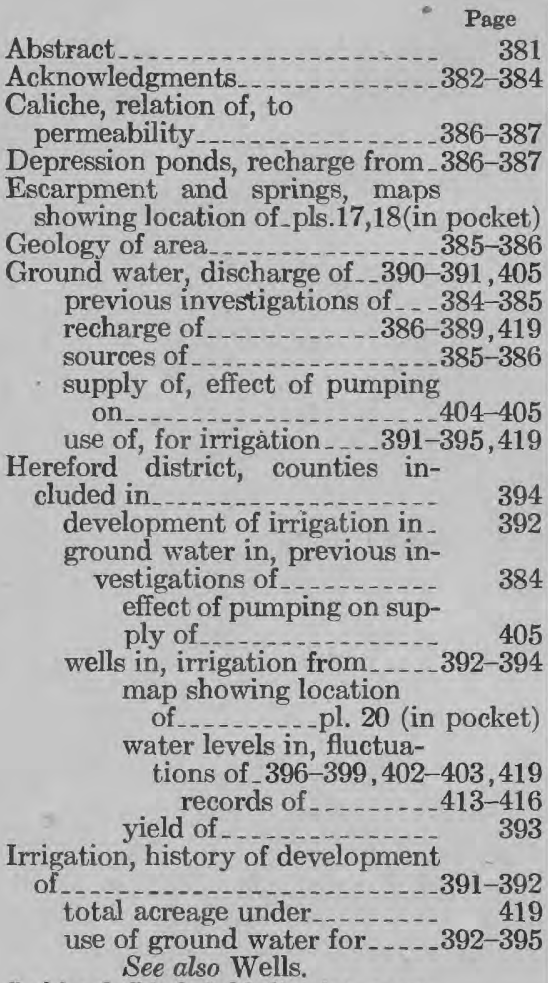

Lubbock-Littlefield district, counties included in wells in, irrigation from water levels in, fluctuations of

Muleshoe district, counties included in ground water in, previous investigations of wells in, irrigation from _..._392-394 map showing location of .......... pl. 21 (in pocket) water levels in, fluctuations of . . . 396-399, 403-404 records of _... $417-418$ yield of 393
Ogallala formation, character and

Page extent of _...

Plainview district, counties included in ground water in, effect of pumping on supply of previous investigations of 384 recharge of

wells in, irrigation from map showing location of _........ pl. 19 (in pocket) water levels in, fluctuations of _...... $396-402$ records of .

Sand-dune areas, recharge in . _ _ 387-389 Sinks, recharge from _.......... 386-387 Spring Lake district, counties included in....... 394 wells in, number of ........ 395 Springs, escarpment, discharge from map showing location of ............pls. 17, 18 (in pocket)

Streams, recharge from .......... 387

Texline district, counties included in wells in, number of ........ 395 water levels in, measurements of

Water levels, fluctuations

of measurements of _.-395-396, 406-419 Water table, decline in ...... $404-406,419$ Wells, acres irrigated by _._._._. 393 development of .......... 391-392 fluctuations of water levels in _........ 387-389, 396-404 location of . . maps showing ............ 383 pls. 19-21 (in pocket) measurements of _._395-396, 406-419 number of $\ldots \ldots$..... $392,394-395,419$ pumping records of _._. yield of $\ldots \ldots \ldots 6,392-394$ 
UNITED STATES DEPARTMENT OF THE INTERIOR

Harold L. Ickes, Secretary

GEOLOGICAL SURVEY

W. E. Wrather, Director

Water-Supply Paper 889

CONTRIBUTIONS TO THE HYDROLOGY OF THE UNITED STATES

1941-43

PAPERS BY

L. K. WENZEL, ARTHUR M. PIPER, W. N. WHITE AND OTHERS 



\section{CONTENTS}

[The letters in parentheses preceding the titles are those used to designate the papers for separate publication]

(A) Water supply of the Dakota sandstone in the Ellendale-Jamestown area, North Dakota, by L. K. Wenzel and H. H. Sand ......

(B) Water-table fluctuations in the Spokane Valley and contiguous area, Washington-Idaho, by Arthur M. Piper and George A. La Rocque, Jr...

(C) Ground-water resources of the Houston district, Texas, by W. N. White, N. A. Rose, and W. F. Guyton

(D) Exploratory water-well drilling in the Houston district, Texas, by Nicholas A. Rose, W. N. White, and Penn Livingston

(E) Chemical character of surface waters of Georgia, by William L. Lamar.--

(F) Ground water in the High Plains of Texas, by W. N. White, W. L. Broadhurst, and J. W. Lang-

\section{ILLUSTRATIONS}

PLATE 1. Map showing the physiographic regions of North Dakota and the location of the Ellendale-Jamestown area

2. Map of the Ellendale-Jamestown area, North Dakota, showing artesian wells and western boundary of area of artesian flow_In pocket

3. Map of North Dakota showing fluoride content of water from Dakota sandstone and Red River Valley artesian basins..........

4. Map of the Spokane Valley and contiguous area, WashingtonIdaho, showing location of observation wells and approximate extent of glacial-outwash plains

5. Fluctuations of the water level in five wells in the Spokane Valley and contiguous area, Washington-Idaho, 1929-38_........ In pocket

6. Fluctuations of the water level in three wells and in the Spokane River in the vicinity of the Spokane municipal pumping stations, 1937-38

7. Fluctuations of the water level in two public-supply wells at Spokane, Wash., 1909-25 and 1927-38_................ In pocket

8. Map of Harris County and adjoining parts of Port Bend and Waller Counties, Tex., showing location of water wells.....In pocket

9. Map of Houston, Tex., and vicinity showing location of water wells

10. Map showing approximate altitude of water level in wells in the Houston district, February $1940 \ldots$

11. Generalized geologic sections in Waller and Harris Counties .... 144

12. Electrical logs of test wells along Houston-Clodine road.......In pocket

13. Electrical logs of test wells near South Houston ........... In pocket

14. Electrical logs of test wells at Westfield _...................

15. Relation of electrical $\log$ to character of water and sand in drillstem samples.

16. Diagram showing for well 6 the relation between resistivity recorded in electrical log (second curve) and permeability and grain sizes of core samples.

17. Map of parts of Briscoe, Floyd, and Motley Counties, Tex, showing approximate location of High Plains escarpment and springs below the escarpment

In pocket

18. Map of Crosby County and a part of Dickens County, Tex., showing approximate location of High Plains escarpment and springs below the escarpment

19. Map of Plainview district, Tex., showing irrigation, city and town, and observation wells_..................... In pocket

20. Map of Hereford district, Tex., showing irrigation, city, and ob-

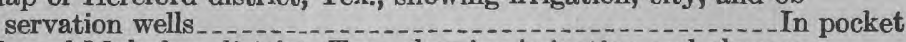

21. Map of Muleshoe district, Tex., showing irrigation and observation wells_................ In pocket 
Figure 1. Diagrammatic section across the Dakota artesian basin .........

2. Graph produced by an automatic water-level recorder showing fluctuations of artesian head caused by changes in atmospheric pressure and emission of gas _............................

3. Profiles of the piezometric surface showing computed decline in artesian head at several distances west of the area of artesian flow

4. Index map of the State of Washington and part of Idaho showing location and extent of the area

5. Fluctuations of water levels in wells in the Pasadena area......

6. Fluctuations of water levels in wells in eastern Houston ........

7. Fluctuations of water levels in wells in central Houston......

8. Fluctuations of water levels in wells west of Houston ..........

9. Fluctuations of water levels in wells north of Houston ..........

10. Graph showing theoretical draw-down, according to the Theis formula, due to pumping a well at a constant rate of $1,000,000$ gallons a day, the aquifer having a coefficient of transmissibility of 160,000 gallons a day and a coefficient of storage of 0.002

11. Map of Harris County, Tex., showing location of test wells .....

12. Diagram showing schematically the arrangement of electrodes used in electrical logging.

13. Diagram showing for well 3 the relation between resistivity recorded in electrical $\log$ (second curve) and permeability and grain sizes of core samples

14. Diagram showing for well 5 the relation between resistivity recorded in electrical log (second curve) and permeability and grain sizes of core samples.........................

15. Relation of chloride in water obtained from test wells by drillstem sampling to resistivity recorded at the same depths by the electrical log

16. Temperature of water of Altamaha River at Doctortown, Ga., 1937-38

17. Temperature of water of Chattahoochee River near Vinings, 1937-38 . .

18. Temperature of water of Chattahoochee River at Columbus, 1940-41.

19. Temperature of water of Chattahoochee River near Hilton, 194041

20. Temperature of water of Etowah River near Cartersville, 1938-39

21. Temperature of water of Ocmulgee River at Macon, 1937-38 ....

22. Temperature of water of Ogeechee River near Eden, 1937-38 ...

23. Temperature of water of Satilla River near Waycross, 1937-38_.

24. Temperature of water of Savannah River near Clyo, 1938-39...

25. Analyses showing minimum and maximum mineral content of waters of Altamaha, Chattahoochee, and Etowah Rivers.

26. Analyses showing minimum and maximum mineral content of waters of Ocmulgee, Oconee, Ogeechee, Satilla, and Savannah Rivers

27. Map of High Plains and adjacent region in northwest Texas showing areas in which most of the irrigation wells are located.

28. Depth to water in wells in areas of ground-water intake, Floyd and Hale Counties, Tex

29. Depth to water in wells near areas of ground-water intake, Lubbock and Deaf Smith Counties, Tex ....................

30. Depth to water in wells in Plainview district, Hale and Floyd Counties, Tex. (areas of moderate pumping).

31. Depth to water in wells in Plainview district, Floyd County, Tex. (areas of heavy pumping) -

32. Depth to water in wells in Hereford district, Deaf Smith County, Tex

33. Depth to water in wells in Muleshoe district, Bailey and Lamb Counties, Tex 